\title{
EVALUATION OF DRIP APPLICATIONS AND FOLIAR SPRAYS OF THE BIOCONTROL PRODUCT ACTINOVATE ON POWDERY MILDEW AND OTHER FUNGAL DISEASES OF TOMATO
}

\author{
A Thesis \\ presented to \\ the Faculty of California Polytechnic State University, \\ San Luis Obispo
}

In Partial Fulfillment

Of the Requirements for the Degree

Master of Science in Agriculture with a Specialization in Soil Science

by

Therese Angelica Quintana-Jones

June 2011 
(C) 2011

Therese Angelica Quintana-Jones

ALL RIGHTS RESERVED 


\section{COMMITTEE MEMBERSHIP}

TITLE:

Evaluation of Drip Applications and Foliar Sprays

of the Biocontrol Product Actinovate on Powdery

Mildew and Other Fungal Diseases of Tomato

AUTHOR:

Therese Angelica Quintana-Jones

DATE SUBMITTED:

June 2011

COMMITTEE CHAIR:

Dr. Lynn E. Moody, Earth and Soil Sciences

Department Head

COMMITTEE MEMBER:

Dr. Michael Yoshimura, Biological Sciences

Professor

COMMITTEE MEMBER:

Dr. Elizabeth Will, Soil Science Lecturer 


\begin{abstract}
Evaluation of Drip Applications and Foliar Sprays of the Biocontrol Product Actinovate on Powdery Mildew and Other Fungal Plant Pathogens of Tomato

Therese Angelica Quintana-Jones
\end{abstract}

The effectiveness of the biocontrol product Actinovate ${ }^{\circledR}$ at enhancing tomato plant growth and yield, and reducing the presence of fungal pathogens was studied in greenhouse and field conditions. In the greenhouse, no differences were found among seed germination or plant survival rates, seedling heights, dry root weights, and dry shoot weights of tomato seedlings grown from seeds drenched with Actinovate ${ }^{\circledR}$ or Rootshield $^{\circledR}$. The effects of one initial Actinovate ${ }^{\circledR}$ seed drench at sowing, repeated applications through the drip irrigation throughout the season, or repeated applications through the drip irrigation plus foliar applications throughout the season at reducing plant infection by fungal plant pathogens, and increasing yield and quality for tomato plants (Solanum lycopersicum) were investigated in Los Alamos, CA, on a sandy loam soil. No significant differences in plant height were found among the four treatments. Marketable fruit weight was greater in the drip plus foliar treatment than in the Actinovate ${ }^{\circledR}$ seed drench treatment. The foliar plus drip treatment resulted in the greatest amount of powdery mildew present, although the disease pressure was low. No significant differences were found among the four treatments in the presence of Verticillium wilt or Sclerotinia.

Keywords: Actinovate, Streptomyces lydicus, biological fungicide, microbial fungicide, biocontrol, tomato, Solanum lycopersicum, powdery mildew, verticillium 


\section{ACKNOWLEDGEMENTS}

I would like to thank my committee chair and advisor, Dr. Lynn E. Moody, for supporting my interests in soil microbiology and plant pathology. Thank you for all of the help, advice, and mentoring.

I am very grateful to Sergio Medrano for his guidance and support, and the use of his farm, labor, materials, equipment, and time. I would like to thank Edgar Ramirez and Greenheart Farms Wholesale Propagation Nursery in Arroyo Grande for the donation and propagation of the tomato plants. I would like to thank Tim Lichatowich and Natural Industries, Inc. for contributing the Actinovate ${ }^{\circledR}$, and the Earth and Soil Sciences Department College Based Fee Committee for contributing funding.

I would like to thank all of the members of my committee for their help and guidance, and Dr. Chip Appel, Craig Stubler, John Bechtold, Nikki Smith, Fernando Quintana, and Suri Gadel-Karim, for their support and assistance. Thank you to Heather Smith and Brent Hughes for their assistance with statistical design and analysis. A special thank you to Adriana Morales for introducing me to so many generous people willing to help me. Thank you to my mom and dad for the constant encouragement, and to Bruce Jones for everything he did to help complete this thesis. 


\section{TABLE OF CONTENTS}

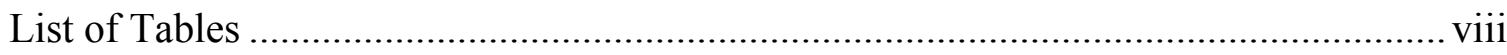

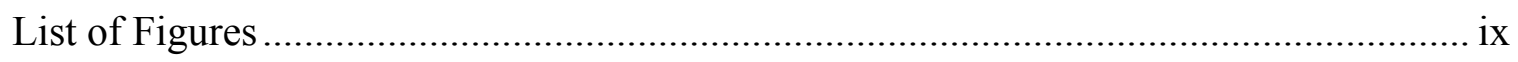

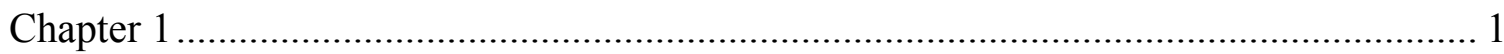

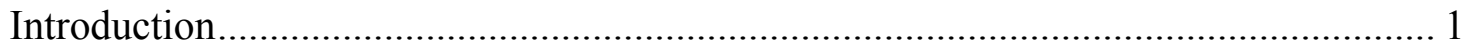

Background Information and Problem Statement .................................................. 1

Statement of Subgoal to be Investigated ........................................................ 2

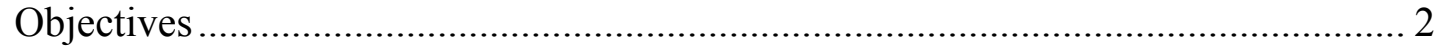

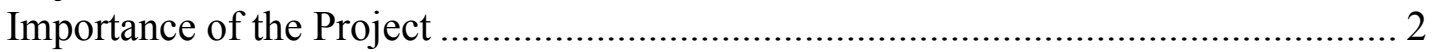

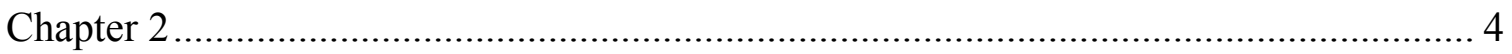

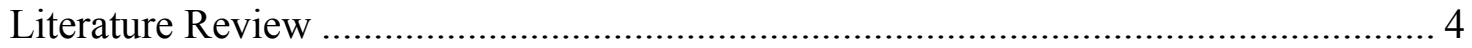

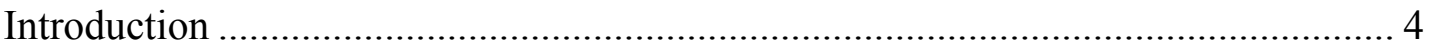

Biocontrol Agents Used to Control Fungal Pathogens of Tomato …………………..... 5

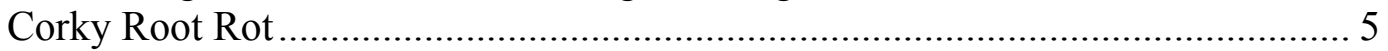

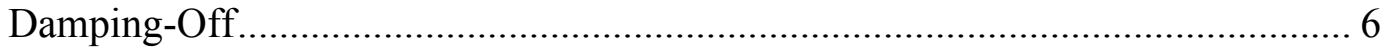

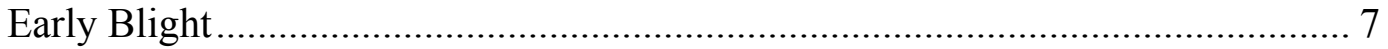

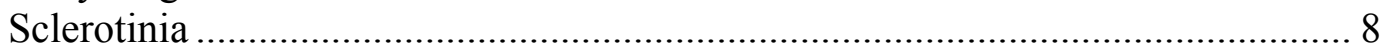

Fusarium Wilt and Verticillium Wilt ............................................................... 9

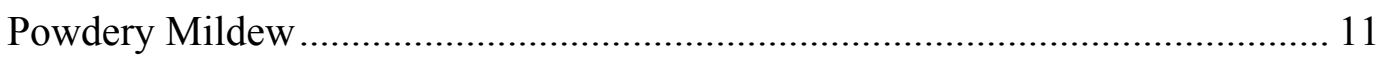

Characterization of Trichoderma harzianum as a Fungal Biocontrol Agent.............. 13

Evaluation of Trichoderma harzianum as a Fungal Biocontrol Agent....................... 14

Characterization of Streptomyces lydicus as a Fungal Biocontrol Agent.................. 16

Production of Extracellular Antibiotics and Enzymes.......................................... 17

Colonization of Plant Roots and Viability in the Soil........................................... 19

Evaluation of Streptomyces lydicus as a Fungal Biocontrol Agent ........................... 20

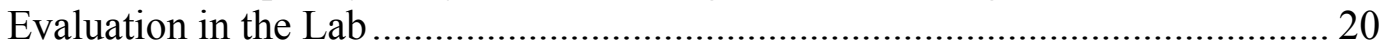

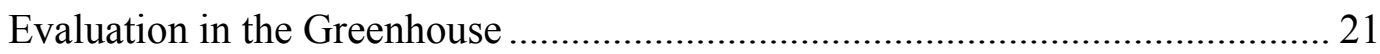

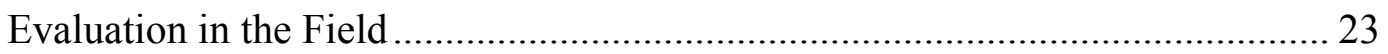

Evaluation of Trichoderma harzianum and Streptomyces lydicus as plant growth promoting organisms ........................................................................................ 24

Trichoderma harzianum as a Plant Growth Promoter ......................................... 24

Streptomyces lydicus as a Plant Growth Promoter ............................................... 25

Benefits of Grower Involvement in Disease Control Experiments ............................ 27

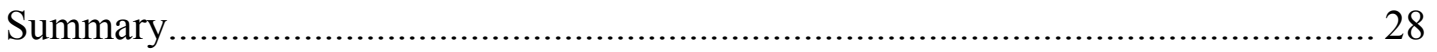

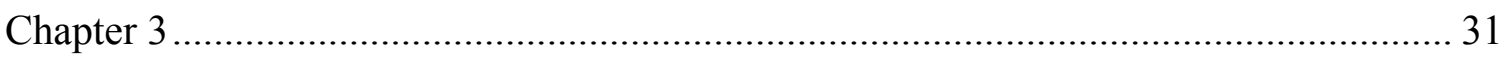

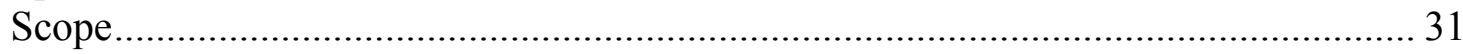

Methods and Materials..................................................................................... 32

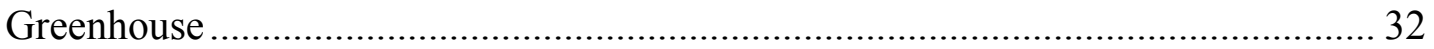

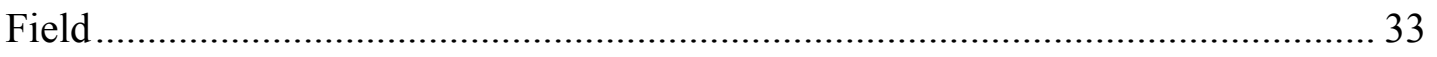

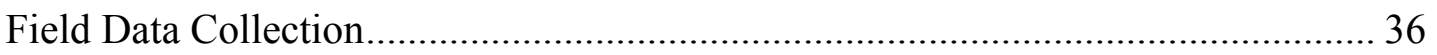

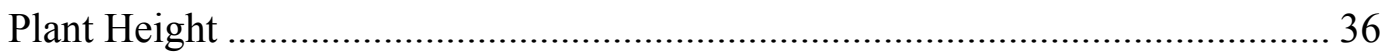

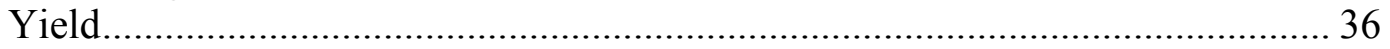

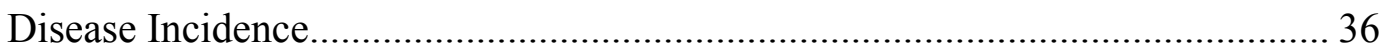

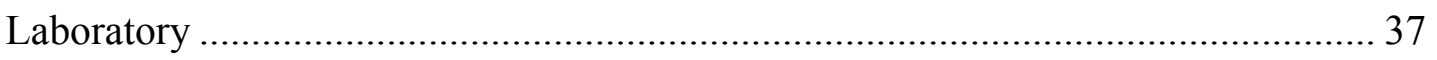




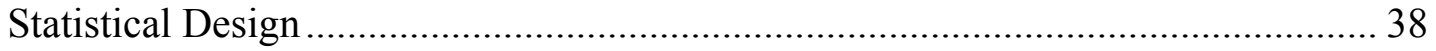

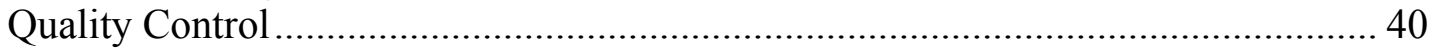

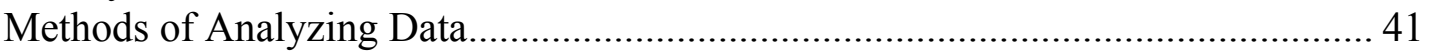

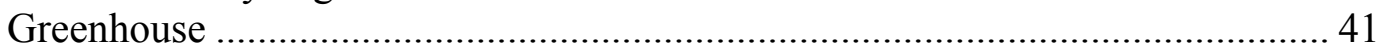

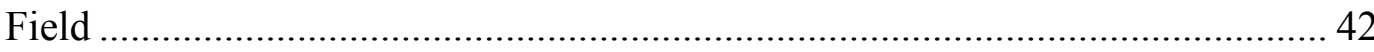

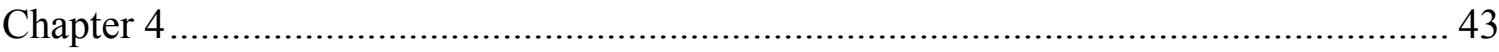

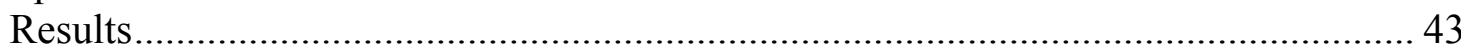

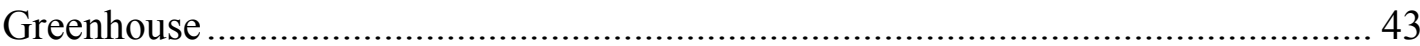

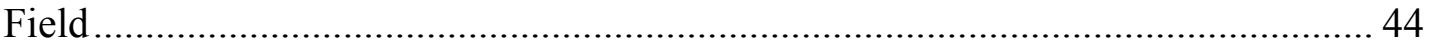

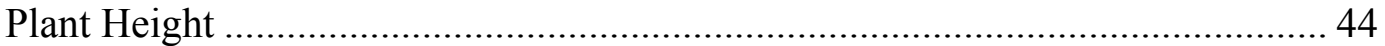

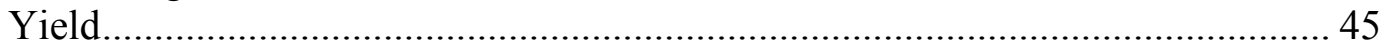

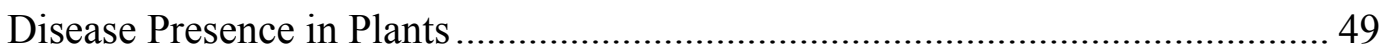

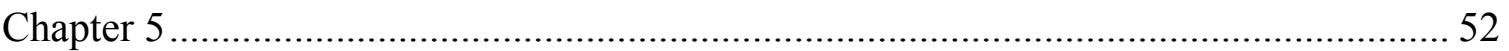

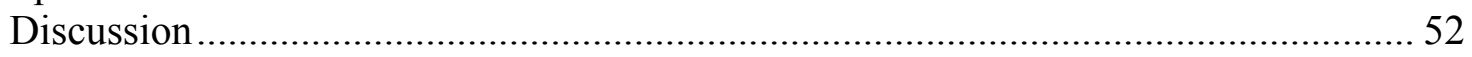

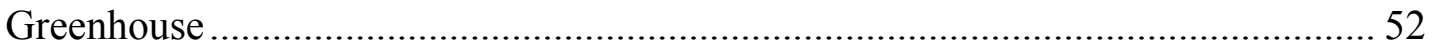

Germination and Survival ....................................................................... 52

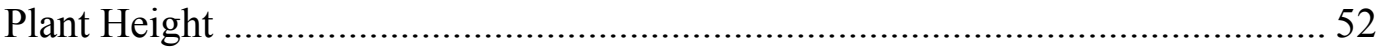

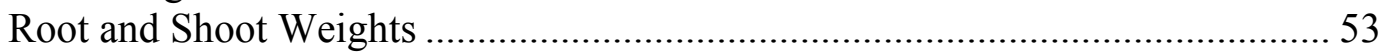

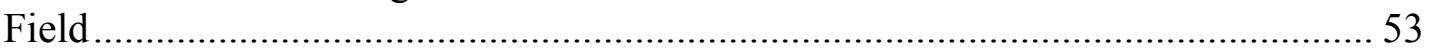

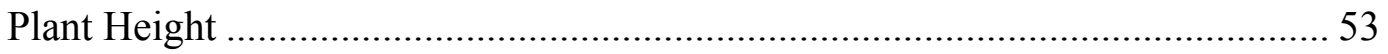

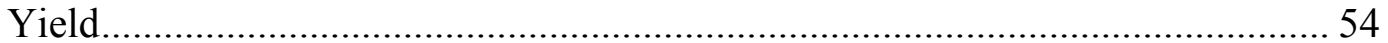

Disease Presence in Plants ............................................................................. 57

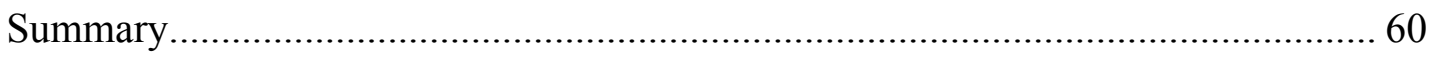

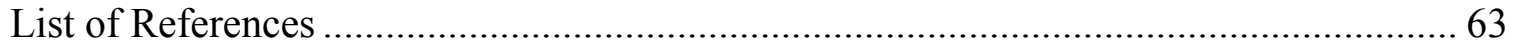

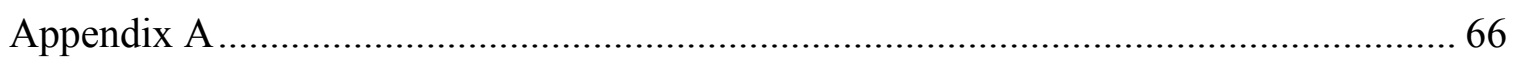

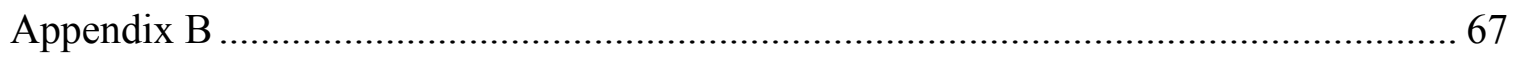

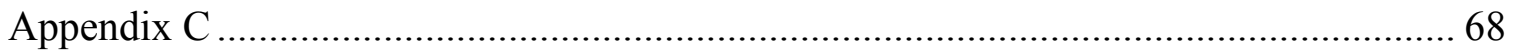

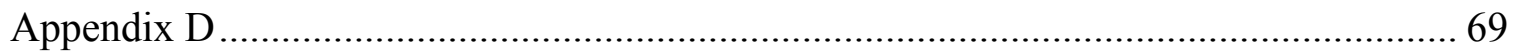




\section{LIST OF TABLES}

Table 2-1. In vitro antagonism of $S$. lydicus WYEC108 (adapted from Yuan and Crawford, 1995).

Table 2-2. Commercial biocontrol products used in a study against Phytophthora ramorum, the causal agent of sudden oak death and ramorum blight (adapted from Elliott et al., 2009).

Table 3-1. Fertilizer, fungicide, and insecticide applications in the organic greenhouse. 32

Table 3-2. Fertilizer and insecticide applications through drip tape during the field trial 35

Table 3-3. Empirical scales used to record fungal disease symptoms and plant vigor..... 36

Table 3-4. Treatments and treatment codes .................................................................... 38

Table 4-1. Effect of drenching seeds with Actinovate ${ }^{\circledR}$ or Rootshield ${ }^{\circledR}$ at time of sowing on mean seedling height, fresh shoot weight, dry root weight, and dry shoot weight on organically grown tomato seedlings 10 weeks after sowing.

Table 4-2. Effect of one initial Actinovate ${ }^{\circledR}$ application at sowing (A), repeated Actinovate ${ }^{\circledR}$ applications through drip tape (AD), repeated drip and foliar Actinovate ${ }^{\circledR}$ applications (ADF), and one initial Rootshield $\mathbb{R}$ application $(\mathrm{R})$ on mean marketable yield weight.

Table 4-3. Effect of one initial Actinovate ${ }^{\circledR}$ application at sowing (A), repeated

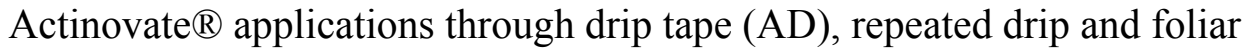
Actinovate ${ }^{\circledR}$ applications (ADF), and one initial Rootshield ${ }^{\circledR}$ application (R) on mean number of marketable fruits in each plot for each harvest day. . 46

Table 4-4. Effect of one initial Actinovate ${ }^{\circledR}$ application at sowing (A), repeated

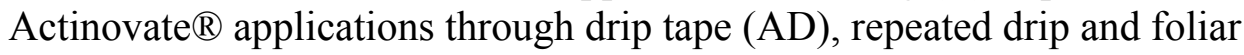

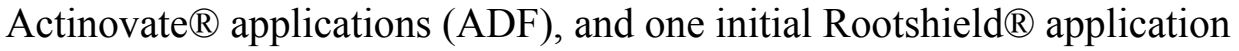

$(\mathrm{R})$ on mean marketable percentage of harvested tomatoes.

Table 4-5. Effect of one initial Actinovate ${ }^{\circledR}$ application at sowing (A), repeated Actinovate ${ }^{\circledR}$ applications through drip tape (AD), repeated drip and foliar Actinovate ${ }^{\circledR}$ applications (ADF), and one initial Rootshield $\AA$ application (R) on percentage of total leaf area with powdery mildew symptoms.. 


\section{LIST OF FIGURES}

Figure

2-1 Production of S. lydicus chitinase on mixed substrate containing 3:1 colloidal chitin and chitin derived from different fungal cell walls (reproduced from Mahadevan and Crawford, 1997).

3-1 The town of Los Alamos, in Santa Barbara County, CA

3-2 General location of the farm where the trial was conducted, outlined in yellow (Left). Location of one acre tomato field trial, in green (Right)...

3-3 18 rows of tomatoes split into 3 blocks with row numbers at top, block numbers center, and treatment codes at bottom. Rows with no specified treatments were buffers for foliar application drift, with no data collected from them....

4-1 Effects of one Actinovate ${ }^{\circledR}$ application (A), repeated drip Actinovate ${ }^{\circledR}$ applications (AD), repeated drip + foliar Actinovate ${ }^{\circledR}$ applications (ADF), and one Rootshield ${ }^{\circledR}$ application (R) on tomato plant height 38 109 days after transplanting. Error bars indicate 95\% Confidence Intervals. Means with overlapping error bars are not significantly different

4-2 Effects of one Actinovate ${ }^{\circledR}$ application (A), repeated drip Actinovate ${ }^{\circledR}$ applications (AD), repeated drip + foliar Actinovate ${ }^{\circledR}$ applications (ADF), and one Rootshield ${ }^{\circledR}$ application (R) on mean tomato yield in $\mathrm{g}$. Error bars indicate $95 \%$ Confidence Intervals. Means with overlapping error bars are not significantly different......................................

4-3 Effects of one Actinovate ${ }^{\circledR}$ application (A), repeated drip Actinovate ${ }^{\circledR}$ applications (AD), repeated drip + foliar Actinovate ${ }^{\circledR}$ applications (ADF), and one Rootshield ${ }^{\circledR}$ application (R) on tomato yield, in number of marketable tomatoes. Error bars indicate 95\% Confidence Intervals. Means with overlapping error bars are not significantly different...........

4-4 Effects of one Actinovate ${ }^{\circledR}$ application (A), repeated drip Actinovate ${ }^{\circledR}$ applications (AD), repeated drip + foliar Actinovate ${ }^{\circledR}$ applications (ADF), and one Rootshield ${ }^{\circledR}$ application (R) on marketable percentage of tomatoes. Error bars indicate 95\% Confidence Intervals. Means with overlapping error bars are not significantly different

4-5 Effects of one Actinovate ${ }^{\circledR}$ application (A), repeated drip Actinovate ${ }^{\circledR}$ applications (AD), repeated drip + foliar Actinovate ${ }^{\circledR}$ applications (ADF), and one Rootshield ${ }^{\circledR}$ application (R) on mean percentage of total leaf area with powdery mildew symptoms. Error bars indicate 95\% Confidence Intervals. Means with overlapping error bars are not significantly different.

4-6 Overall plant vigor for tomatoes treated with one Actinovate ${ }^{\circledR}$ application (A), repeated drip Actinovate ${ }^{\circledR}$ applications (AD), repeated drip + foliar Actinovate $^{\circledR}$ applications (ADF), and one Rootshield ${ }^{\circledR}$ application (R). Error bars indicate $95 \%$ Confidence Intervals. Means with overlapping error bars are not significantly different. 


\section{CHAPTER 1}

Introduction

\section{Background Information and Problem Statement}

Fresh market tomatoes (Solanum lycopersicum, formerly Lycopersicon esculentum Mill.) are an important commodity in the United States. Average per capita consumption of fresh tomatoes in the U.S. increased from 12.3 pounds in 1981 to 20.3 pounds in 2007. The production of fresh market tomatoes in the U.S. in 2007 was valued at $\$ 1.2$ billion, second only to the highest ranked fresh market vegetable, head lettuce, at $\$ 1.3$ billion. California and Florida are the top two states producing fresh market tomatoes, with each producing approximately a third of the nation's tomatoes each year (Boriss and Brunke, 2009).

Biological control methods are being increasingly used in crop production as an alternative to chemical fungicides to control diseases in vegetable crops caused by fungal plant pathogens. This is due to concerns about the environment and human safety, plant pathogens increasingly developing resistance to chemicals, and increasing regulation of chemical fungicide use (Elliott et al., 2009).

The actinomycete Streptomyces lydicus is a biocontrol agent which can control many fungal plant pathogens of vegetable crops (Mahadevan and Crawford, 1997). Streptomyces lydicus WYEC108 is a strain of this species which has been formulated in the commercially available product Actinovate $^{\circledR}$, and it may be able to control fungal plant pathogens effectively for fresh market tomatoes. 


\section{Statement of Subgoal to be Investigated}

The biological fungal control product Actinovate ${ }^{\circledR}$ may increase seedling germination and survival rates, seedling height, and seedling shoot and root weights compared to seedlings treated with Rootshield ${ }^{\circledR}$ in a greenhouse setting. In the field trial, Actinovate ${ }^{\circledR}$ applied once as a seed drench or repeatedly through the drip irrigation line or through the irrigation line in combination with regular foliar applications, may increase tomato plant height and yield, and decrease the presence of foliar and soil borne fungal plant pathogens.

\section{Objectives}

The objectives of this study are to (i) evaluate the efficacy of Actinovate ${ }^{\circledR}$ on tomato germination, seedling survival, and dry root and shoot mass in greenhouse conditions 10 weeks after sowing; and (ii) evaluate drip and foliar applications of the commercial biological control product Actinovate ${ }^{\circledR}$ on tomato plant growth and against Leveillula taurica, the causal agent of powdery mildew, Verticillium dahliae Kleb. The causal agent of Verticillium wilt, and other fungal plant pathogens on Solanum lycopersicum in field conditions. Tomato plant height, yield, and presence of fungal diseases were measured to make this evaluation.

\section{Importance of the Project}

Biocontrols are being increasingly used in agriculture, partly due to concerns about the effects of chemical fungicides on the environment and human safety, and plant pathogens developing resistance to chemicals. The effectiveness of the biocontrol 
Actinovate $^{\circledR}$ in vegetable crops in field situations has been studied relatively little compared to other biocontrol products, and there has been no research published about using Actinovate ${ }^{\circledR}$ with fresh market tomatoes. The results of this study can be used by producers of not only fresh market tomatoes, but possibly of other crops, such as processing tomatoes and peppers, to make better management decisions about fungicide use. Producers of tomatoes and similar crops in California, the rest of the U.S., and the world who have similar environmental conditions can use this information. 


\section{CHAPTER 2}

Literature Review

\section{Introduction}

Tomato (Solanum lycopersicum) is the second most important vegetable crop in the world. It is consumed as a fresh vegetable, in ketchup, as a puree, and in many other forms. Many different fungal diseases cause crop losses in tomato worldwide. Major fungal diseases affecting tomato production worldwide are late blight, early blight, septoria leaf spot, Fusarium wilt, and Verticillium wilt. Other important diseases are powdery mildew and leaf mold (Panthee and Chen, 2010).

Biological control methods are being increasingly used in agriculture as an alternative to chemical fungicides to control diseases caused by fungal plant pathogens. Public objections against pesticides and growing legislative pressure to reduce their use in agriculture are increasing (Segarra et al., 2009). This is due to concerns about the environment and human safety, and plant pathogens developing resistance to chemicals. Many different types of organisms can control fungal pathogens of fruit and vegetable crops. Biocontrol organisms can use different mechanisms to reduce damage caused by plant pathogens (Elliott et al., 2009). The actinomycete Streptomyces lydicus can control many fungal plant pathogens of vegetable crops (Mahadevan and Crawford, 1997).

Several important diseases of tomato reduce crop yield, and several microorganisms have been used to control them. The characterization and modes of action of the fungus Trichoderma harzianum and the actinomycete Streptomyces lydicus as biocontrol agents of fungal plant pathogens will be discussed in this section, focusing on the strain S. lydicus WYEC108. The evaluation of T. harzianum and S. lydicus 
WYEC108 as biocontrol agents of fungal plant pathogens and as plant-growth promoters in laboratory, greenhouse, and field conditions will be also be discussed. Finally, the importance and benefits of incorporating grower input and using appropriate technology and methods when conducting research will be discussed.

\section{Biocontrol Agents Used to Control Fungal Pathogens of Tomato}

Various biocontrol agents currently are currently used or being studied for their abilities to control several important diseases of tomatoes. The diseases, which include corky root rot, damping-off, early blight, sclerotinia Fusarium wilt, Verticillium wilt, and powdery mildew, are discussed here with the biocontrol agents showing promise of controlling each.

\section{Corky Root Rot}

The soil borne disease corky root rot is caused by the fungus Pyrenochaeta lycopersici. Symptoms of the disease include wilting, interveinal and peripheral chlorosis, and defoliation. Small feeder roots often rot, other small roots develop smooth, brown lesions, and large roots develop dry, furrowed bark. The fungus persists in the soil as microsclerotium. In California, it occurs in the San Joaquin, the lower Sacramento, and the central coastal valleys (University of California, 1990). Severe infections can greatly reduce yields. In organic tomato production in Sweden, corky root rot can reduce yields by up to $75 \%$. Organic farmers currently use crop rotation, resistant cultivars, manuring, grafting onto disease-tolerant rootstocks, and biocontrol agents to control this disease (Hasna et al., 2009).

Four commercially available biocontrol agents were evaluated for their ability to control corky root disease at the Swedish University of Agricultural Sciences. The 
biocontrol products were Binab $\mathrm{TF} \mathrm{WP}^{\circledR}$, based on Trichoderma harzianum and $\mathrm{T}$. polysporum; Mycostop ${ }^{\circledR}$, based on Streptomyces griseoviridis strain K61; Prestop WP ${ }^{\circledR}$, based on Gliocladium catenulatum strain J1446; and Glio Mix ${ }^{\circledR}$ based on Gliocladium spp. They were tested in vitro and in greenhouse experiments. All of these biocontrol agents inhibited the growth of $P$. lycopersici in vitro, and the biocontrols all worked better in nutrient-rich media than in nutrient-poor media. Access to exogenous nutrients is known to enhance the ability of Trichoderma spp. to control fungal pathogens. In the

greenhouse experiment, all treatments except Prestop $\mathrm{WP}^{\circledR}$ led to healthier roots than the control (Hasna et al., 2009). All four commercially available biocontrols reduced the occurrence of corky root disease in vitro, and most reduced corky root rot occurrence in the greenhouse.

\section{Damping-Off}

Damping-off is a general term for the death of seedlings under damp conditions, either before or after seedling emergence. Symptoms can include the seedling rotting, lesions, or cankers. Damping-off can be caused by many fungal pathogens, including Phytophthora spp., Pythium spp., Rhizoctonia spp., and Sclerotium rolfsii (University of California, 1990).

The efficacy of two novel biocontrol isolates, strains of Burkholderia cepacia and Pseudommonas sp., were evealuated against Rhizoctonia solani Kühn and Sclerotium rolfsii Sacc. on tomato plants in growth chamber and field conditions in Italy, where a high incidence of damping-off caused by the pathogens occurred. The efficacy of the bacterial isolates when applied in the field through the drip irrigation system was also evaluated. Two other biocontrol products were also tested: BSF4, based on Bacillus 
subtilis, and TV1, based on Trichoderma asperellum, as well as several chemical fungicides. Several species of Pseudomonas were effective antagonists of fungal pathogens and as plant-promoting rhizobacteria (De Curtis et al., 2010).

For the field experiment, tomato plants were artificially wounded on the stem at the crown, and then sprayed with the biocontrol treatments. Twenty-four hours later, the plants were inoculated with the pathogens $R$. solani and $S$. rolfsii before transplanting. Seven days later, the biocontrol treatments were repeated three times per week through the drip irrigation system. Treatments were applied through drip emitters on commercial flexible tape. Disease incidence and severity were assessed weekly, and disease indices were calculated (De Curtis et al., 2010).

In the growth chamber experiments, $B$. cepacia significantly inhibited dampingoff caused by $S$. rolfsii, reducing the disease index by $81 \%$ compared to the untreated control (pathogen alone), but it did not significantly inhibit damping-off caused by $R$. solani. In the field experiments, treatment with the chemical fungicide toclofos-methyl was the most effective both years for both pathogens, with $100 \%$ disease reduction. Except for the T. asperellum treatment against S. rolfsii in 2007, all of the biocontrols significantly reduced disease severity caused by both pathogens in both years (De Curtis et al., 2010).

\section{Early Blight}

Early blight is caused by the fungal pathogen Alternaria solani. Symptoms begin as small dark brown lesions on the older foliage. The tissue surrounding lesions may turn yellow, turning entire leaves yellow when the spots are abundant. Stem lesions on seedlings can girdle the plants. In California, early blight occurs in coastal areas. It 
mainly affects tomatoes that are exposed to rain, and disease development stops in hot, dry weather. Alternaria solani spores are carried by wind and require moisture to germinate. Most varieties of tomatoes grown in California are susceptible (University of California, 1990).

Streptomycetes are known to include several antagonistic species that may inhibit growth of plant pathogenic microorganisms. The effects of Streptomyces pulcher and $S$. canescens on the growth of $A$. solani on tomato in vitro were investigated in Egypt. Tomato seeds were sown into soil infested with $A$. solani with the antagonists applied to the soil as a pretreatment, or to the seed as a seed-soak or seed-coat treatment. Both antagonists significantly inhibited $A$. solani growth. Early blight infection symptoms in plants in untreated soil infested with $A$. solani and plants with the seed-soak treatment occurred at $86.4 \%$ and $57.1 \%$, respectively, by day 63 after sowing. No symptoms appeared in the pre-inoculation and seed-coat treatments. Soil inoculation with the antagonist 7 days before sowing was less effective than seed-coating in controlling tomato pathogens. (Elabyad et al., 1993).

\section{Sclerotinia}

Sclerotinia is caused by the fungal pathogens Sclerotinia sclerotiorum and $S$. minor. Infected stems become soft, and large portions of invaded tissue my die. Infected stems turn light gray. White mycelium often appears on diseased stems in cool, moist weather, and sclerotia are produced on mycelial mats and inside stems. They infect tomatoes when the soil is wet, usually late in the season when plants have a welldeveloped canopy. The disease is common in tomato growing areas, but usually only 
affects scattered spots in the field and rarely cause significant losses (University of California, 1990).

Biocontrol agents characterized for the control of S. sclerotiorum include the mycoparasitic fungus Ulocladium atrum, the antibiotic-producing Pseudomonas spp., the actinomycete Trichoderma harzianum, and the fungus Epicoccum purpurescence. Commercially available Plantshield ${ }^{\circledR}$, based on T. harzianum, and SoilGard ${ }^{\circledR}$, based on Gliocladium virens were evaluated in Kuwait for their ability to control S. sclerotiorum on tomato seedlings. Tomato seeds were grown in growth chambers and in a greenhouse, and at the three-leaf stage, they were inoculated with the biocontrol agents. All tomato seedlings were inoculated with $S$. sclerotiorum. In the growth chambers, the tomato plots with seeds treated with PlantShield ${ }^{\circledR}$ or SoilGard ${ }^{\circledR}$ had significantly higher percentages of healthy plants (both $100 \%$ ) than the plots with no biocontrols applied (24.0\%). In the greenhouse, the seeds treated with PlantShield ${ }^{\circledR}$ and those treated with SoilGard ${ }^{\circledR}$ resulted in significantly lower percentages of infected plants (approximately $11 \%$ and $10 \%$, respectively) than the seeds with no biocontrols applied (approximately $70 \%$ infected). Both PlantShield $^{\circledR}$ and SoilGard ${ }^{\circledR}$ decreased the presence of Sclerotinia in tomatoes (Abdullah et al., 2008).

\section{Fusarium Wilt and Verticillium Wilt}

Fusarium wilt is caused by the soil borne fungus Fusarium oxysporum $\mathrm{f}$. sp. lycopersici, which infects plants through the rootlets and spreads throughout the xylem. The infected plants usually die. Once established in a field, the fungus remains in the soil indefinitely and invades plants when conditions are suitable. Resistant tomato varieties 
provide effective control in most California tomato crops (University of California, 1990).

Verticillium wilt is caused by the fungal pathogens Verticillium dahlia and $V$. albo-atrum, and is a very destructive disease found in most cultivated soils in California. The disease reduces plant vigor and yield, and can result in plant death. Defoliation caused by the disease can expose the fruit to sunburn. It can remain viable indefinitely in a field once established. Resistant varieties of tomato usually control the disease in California (University of California, 1990; Jones et al., 1991).

The effects of Streptomyces pulcher and S. canescens on the growth of the fungal plant pathogens Fusarium oxysporum f. sp. lycopersici and Verticillium albo-atrum in vitro and on plant growth in vivo were evaluated in Egypt. Tomato seeds were sown into soil infested with the plant pathogens with the antagonists applied to the soil as a pretreatment, or to the seed as a seed-soak or seed-coat treatment, with the control having no antagonists added. Streptomyces pulcher and $S$. canescens significantly inhibited the growth of both fungal pathogens. Fusarium wilt infection symptoms appeared 42 days after sowing. Of the control plants, $17.9 \%$ wilted, compared to only $7.7 \%$ of the plants in the soil pre-innoculation treatment. None of the plants with the seed-soak and seed-coat treatments wilted. At 63 days, $100 \%$ of the control plants were infected, $57.1 \%$ of the seed-soak treatment plants were infected, and $42.9 \%$ of the plants in the soil preinoculation treatment. Plants grown in the presence of the pathogen alone had decreased root depth and dry weight compared to the seed-coat treatment. At 63 days, $57 \%$ of the seed-soaked plants wilted due to Verticillium infection, compared to $100 \%$ of the control 
plants. Seed-coating with S. pulcher was the most effective treatment for controlling Verticillium wilt and supporting plant growth (Elabyad et al., 1993).

Several novel biocontrol strains of Pseudommonas sp. and P. putida, as well as the commercial biocontrol products RootShield ${ }^{\circledR}$, based on T. harzianum, and Cedomon ${ }^{\circledR}$, based on $P$. chlororaphis were evaluated against Fusarium wilt of tomato in greenhouse conditions in Italy. Tomato seeds (cv. Cuore di bue) were sown into plug trays and transplanted after 21 days. Biocontrol agents were added to the soil in pots on the first day of the experiment in all trials, with some treatments having an additional application on day 7 , and with the pathogen added to the soil with the biocontrol agents on the first day, or 7 days after the biocontrol was added. The biocontrols used effectively reduced Fusarium wilt incidence on tomato plants in greenhouse conditions. Rootshield ${ }^{\circledR}$ reduced Fusarium wilt as well as Cedomon ${ }^{\circledR}$ did. Overall, S. pulcher and S. canescens significantly inhibited growth of both fungal pathogens (Srinivasan et al., 2009).

\section{Powdery Mildew}

Powdery mildew of tomato in California is caused by Oidiopsis sicula Scalia, which is the scientific name of the conidial (asexual) stage of the fungal pathogen Leveillula taurica. Other causal agents of powdery mildew in California are Erysiphe orontii, E. polygoni, and the recently renamed Oidium neolycopersici, which is among the principal tomato diseases in greenhouse conditions (Bardin et al., 2008). Powdery mildew has caused significant losses in some fields in coastal California. It increases fruit sunburn through defoliation. Its spores are carried by wind. Powdery mildew damage is increased when plants are stressed due to heavy fruit load or insufficient water. Most 
varieties grown in California are susceptible (University of California, 1990; Panthee and Chen, 2010; Jones et al.,1991).

Compost extracts have successfully controlled leaf diseases caused by Botrytis cinerea and Venturia inequalis, and powdery mildew, sometimes with an effectiveness similar to chemical fungicides. The effects of an aerated compost tea on powdery mildew caused by Erysiphe polygoni in tomato plants in an unheated greenhouse were studied. Tomato (S. lycopersicum cv. Roma) seeds were sown into vermiculite seedling trays in a greenhouse that was severely infected by E. polygoni during the previous season. Compost obtained from market, urban, and garden wastes was used to make the compost tea. Compost tea treatment significantly reduced the percentage of leaves infected, from $51.4 \pm 3.3 \%$ when untreated, to $41.6 \pm 2.5 \%$ of untreated leaves infected. Applying compost tea to leaves led to the replacement of white patches typical of E. polygoni infection with yellow spots with little to no pathogen mycelia, indicating that the compost tea killed or removed the pathogen from the leaves. Applying compost tea to the foliage reduced the incidence of powdery mildew significantly, but only slightly (Segarra et al., 2009).

Powdery mildew is one of the main foliar diseases affecting tomato in commercial organic production fields in Long Island, NY. It can decrease yield and worsen fruit quality. 'Paragon' or 'Red Sun' tomato seedlings were sown into seed trays in 2003 and 2006 and were transplanted into the field 6-8 weeks after sowing. Treatments to suppress powdery mildew were applied to foliage. Compost tea was applied alone and in combination with the biofungicide Sonata ${ }^{\circledR}$, based on Bacillus pumilus, and the citric acid product Agrilife ${ }^{\circledR}$. In 2003, disease severity and defoliation were lowest where Sonata ${ }^{\circledR}+$ 
compost tea were applied, although the difference was not significant. Agrilife ${ }^{\circledR}$ significantly reduced powdery mildew severity in 2006 (McGrath, 2009).

A plant extract from the giant knotweed Reynoutria sachalinensis has efficiently controlled powdery mildew caused by $O$. neolycopersici and L. taurica on tomato (Bardin et al., 2008). Several rhizobacteria were tested for their ability to induce systemic plant resistance of tomato treated tomato seeds against Oidium neolycopersici. One of the strains was an actinomycete. All three rhizobacteria significantly reduced the average number of lesions per leaflet produced by $O$. neolycopersici. Each rhizobacterium may activate different defense mechanisms within the induced resistance pathway, including physical (lignification) and chemical (quinones) barriers (Silva et al., 2004). Little is known about the ability to control powdery mildew in tomato using biocontrols. Formulations of S. lydicus to control powdery mildew in tomato have not been studied.

\section{Characterization of Trichoderma harzianum as a Fungal Biocontrol Agent}

The main mechanisms employed by biocontrol agents to control fungal plant pathogens are competition for space and nutrients, mycoparasitism, secretion of bioactive molecules, and stimulation of the plant's defenses (De Curtis et al., 2010). One mechanism allowing Trichoderma harzianum to control the fungal pathogens Fusarium oxysporum f. sp. vasinfectum and F. oxysporum f. sp. melonis in cotton and melon is its ability to grow quickly and produce cellulase, enabling it to colonize substrates also used by the pathogens. Strains of T. harzianum are used as mycoparasitic biocontrol agents, whereby they directly parasitize hyphae and sclerotia of plant pathogens such as Rhizoctonia solani and Sclerotium by attaching to the pathogenic fungi and secreting lytic enzymes like 1,3-ß-glucosidases and chitinases capable of degrading fungal hyphae. 
Coiling capacity of $T$. hazianum is an important factor for biocontrol against $R$. solani. Coiling capacity was studied in fifteen novel strains of Trichoderma, and all fifteen isolates produced dense coils around $R$. solani hyphae, and then penetrated the hyphae. Other mechanisms used by T. harzianum to control fungal pathogens include suppression of the pathogen's hydrolytic enzymes, induced host resistance, where natural plant defense mechanisms are activated, and antibiosis, where antagonists produce substances toxic to the pathogens (Cuevas et al., 2005; Almeida et al., 2007).

\section{Evaluation of Trichoderma harzianum as a Fungal Biocontrol Agent}

In greenhouse experiments, Binab ${ }^{\circledR}$, a commercially available biocontrol product based on T. harzianum, was tested against Pyrenochaeta lycopercisi, the fungus causing corky root disease in tomato. Plants treated with Binab ${ }^{\circledR}$ had healthier roots than the control. Binab ${ }^{\circledR}$ inhibited P. lycopercisi better in nutrient-rich media than nutrient-poor media, suggesting that adding nutrients to the soil environment could improve their ability as biocontrol agents (Hasna et al., 2009).

The commercial biocontrol product RootShield ${ }^{\circledR}$, based on T. harzianum, effectively reduced Fusarium wilt incidence on tomato plants in greenhouse conditions in Italy. The greatest reduction in Fusarium wilt compared to the inoculated control occurred when soil was inoculated with Rootshield ${ }^{\circledR}$ seven days before the pathogen was applied in addition to the day the pathogen was applied, indicating that it is beneficial to establish the antagonist population in the soil before the pathogen is introduced (Srinivasan et al., 2009).

One-time application of Trichoderma controlled diseases caused by the soil borne pathogens Pythium spp., Sclerotium rolfsii, and Rhizoctonia solani, present in a field in 
the Philippines. A dry pellet formulation of T. harzianum was incorporated into the topsoil two weeks before sowing, resulting in significantly higher seed germination of Black Behi (Brassica chinensis) one week after sowing compared to the untreated control ( $83 \%$ and $76 \%$, respectively). Of the germinated seeds, none of those treated with $T$. harzianum died due to post-emergence damping off, compared to the significantly higher $19 \%$ of control seedlings. There was a significant positive correlation between percent seed germination/percent seedling survival and the logarithm of mean colony forming units of T. harzianum recovered from the soil 6 weeks after the pellets were incorporated into the soil. Seedlings treated with $T$. harzianum were taller and had bigger leaves compared to those in the control (Cuevas et al., 2005).

In plots heavily infested with Sclerotium rolfsii, at the University of the Philippines Los Baños Central Experiment Station, dry pellets of T. harzianum were incorporated into the topsoil two weeks before tomato seeds (S. lycopersicum 'Apollo') were sown. Control plots had no T. harzianum pellets incorporated before sowing. Germination and survival of tomato seeds treated with T. harzianum (74\% and 77\%, respectively) were significantly higher than those of the control (34\% and $31 \%$, respectively). The average height of seedlings treated with $T$. harzianum, $11.1 \mathrm{~cm}$, was significantly higher than that of the control, $2.7 \mathrm{~cm}$. The average weight of seedlings treated with T. harzianum, $0.354 \mathrm{~g}$, was higher than that of the control, $0.204 \mathrm{~g}$, although the difference was not significant (Cuevas et al., 2005).

One-time application of Trichoderma pellets resulted in significantly higher yield of eggplant (Solanum melongena cv. 'Long Purple') in a field in the Philippines. Dry pellets with a mixture of three species of Trichoderma, including T. harzianum, were 
incorporated into the topsoil two weeks before eggplant seeds were sown. Another treatment was soil drenched with the chemical fungicide mancozeb one week before sowing, and sprayed onto the seedlings once per week afterward. Control plots were not treated with the biocontrol or chemical control products. Treatment with Trichoderma mixture resulted in a significantly higher number of fruit-bearing plants per plot, compared to the plots treated with mancozeb and the untreated control $(58,49$, and 24 , respectively). Treatment with the Trichoderma mixture resulted in a significantly higher total weight of acceptable quality fruits per plot compared to the plots treated with mancozeb and the untreated control (13.06, 8.65, and $3.45 \mathrm{~kg}$, respectively). Treatment with the Trichoderma mixture resulted in a significantly lower number of viable sclerotia per plot remaining in the soil after harvest compared to the plots treated with mancozeb and the untreated control $(9,16$, and 21 , respectively). Thus, one-time application of dry Trichoderma pellets resulted in significantly decreased the number of sclerotial bodies of Rhizoctonia solani, leading into a lower incidence of the disease in the next cropping season, a result not occurring with chemical fungicide (Cuevas et al., 2005). Trichoderma harzianum may perform better in nutrient-rich soils, and has shown promise for reducing corky root disease, Fusarium wilt, and damping-off in tomato.

\section{Characterization of Streptomyces lydicus as a Fungal Biocontrol Agent}

Streptomyces lydicus WYEC108 acts as a fungal biocontrol agent through many mechanisms, with varying capabilities to control fungal pathogens. WYEC108 produces antifungal antibiotics and extracellular chitinase, and it can colonize plant roots and remain viable in the soil. 


\section{Production of Extracellular Antibiotics and Enzymes}

Streptomyces spp. can produce a wide range of antibiotics and secondary metabolites, and a range of enzymes, which degrade fungal cell walls, including cellulases, hemicellulases, chitinases, amylases, and glutinases (Beyer and Deikmann, 1985). Streptomyces lydicus WYEC108 is a strain of S. lydicus that was isolated from the rhizosphere of linseed plants (Mahadevan and Crawford, 1997). It is antagonistic against many fungal plant pathogens. Several fungal root pathogens tested in vitro were moderately to very sensitive to antifungal metabolites released by WYEC108 (Table 2-1). Streptomyces lydicus WYEC108 caused local death or prolonged inhibition of Pythium ultimum and Aphanomyces euteiches hyphae adjacent to WYEC108. When examined at 40x magnification, no lysis of hyphal tips was observed, indicating that the inhibition of fungal growth was due to excreted antifungal compounds rather than cell wall degrading enzymes (Yuan and Crawford, 1995).

Table 2-1. In vitro antagonism of S. lydicus WYEC108 (adapted from Yuan and Crawford, 1995).

\begin{tabular}{|c|c|c|}
\hline Pathogen & Antagonism $^{\text {a at day } 5}$ & Viability ${ }^{\mathrm{b}}$ at day 5 \\
\hline Pythium ultimum $P 8$ & +++ & - \\
\hline Pythium ultimum P9 & +++ & - \\
\hline Aphanomyces euteiches A15 & +++ & - \\
\hline Aphanomyces euteiches Bob-F1 & +++ & - \\
\hline Aphanomyces euteiches A6 & +++ & - \\
\hline Aphanomyces euteiches Aph4 & +++ & - \\
\hline Fusarium oxysporum & ++ & + \\
\hline Fusarium solanif. sp. pisi & + & + \\
\hline Fusarium solanif. sp. pisi F6 & ++ & + \\
\hline Fusarium solanif. sp. pisi F46 & ++ & + \\
\hline Fusarium solanif. sp. pisi F9 & + & + \\
\hline Rhizoctonia solani & ++ & + \\
\hline Rhizoctonia solani $R 4$ & ++ & + \\
\hline Rhizoctonia solani $W 1$ & ++ & + \\
\hline Rhizoctonia solani X5FS & ++ & + \\
\hline Phymatotrichum omnivorum & ++ & + \\
\hline
\end{tabular}

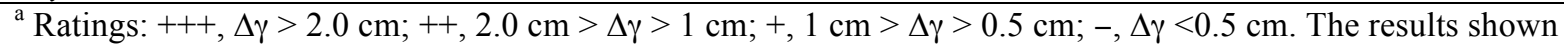
are averages of five replications of each pathogen.

${ }^{\mathrm{b}}$ Viability was evaluated as recovery of mycelial plugs on fresh PDA or CMA plates (-, no growth; +, growth). 
Chitinase-producing bacteria are used to control soil borne plant pathogenic fungi because chitin in the hyphal apex of fungi is sensitive to chitinase, unlike the highly crystalline and rigid chitin in fungal cell walls (Inbar and Chet, 1991). Streptomyces lydicus WYEC108 produces antifungal antibiotics and extracellular chitinase to control fungal plant diseases. WYEC108 chitinase production can be induced with low levels of chitin, and is subject to catabolite repression by sugars. Chitinase production was repressed when xylose, raffinose, glucose, or arabinose were added to WYEC108 growing in $1 \%$ colloidal chitin. Chitinase production increased when fungal cell wall chitin was added to colloidal chitin, especially when the chitin was derived from Aphanomyces euteiches or Pythium ultimum (Fig. 2-1). The chitinase degraded the cell walls of P. ultimum and Rhizoctonia solani, as indicated by the release of sugars from the cell walls. The ability of WYEC108 to produce chitinase in the presence of low levels of fungal chitin, and to produce less chitinase in the presence of simple sugars increase its

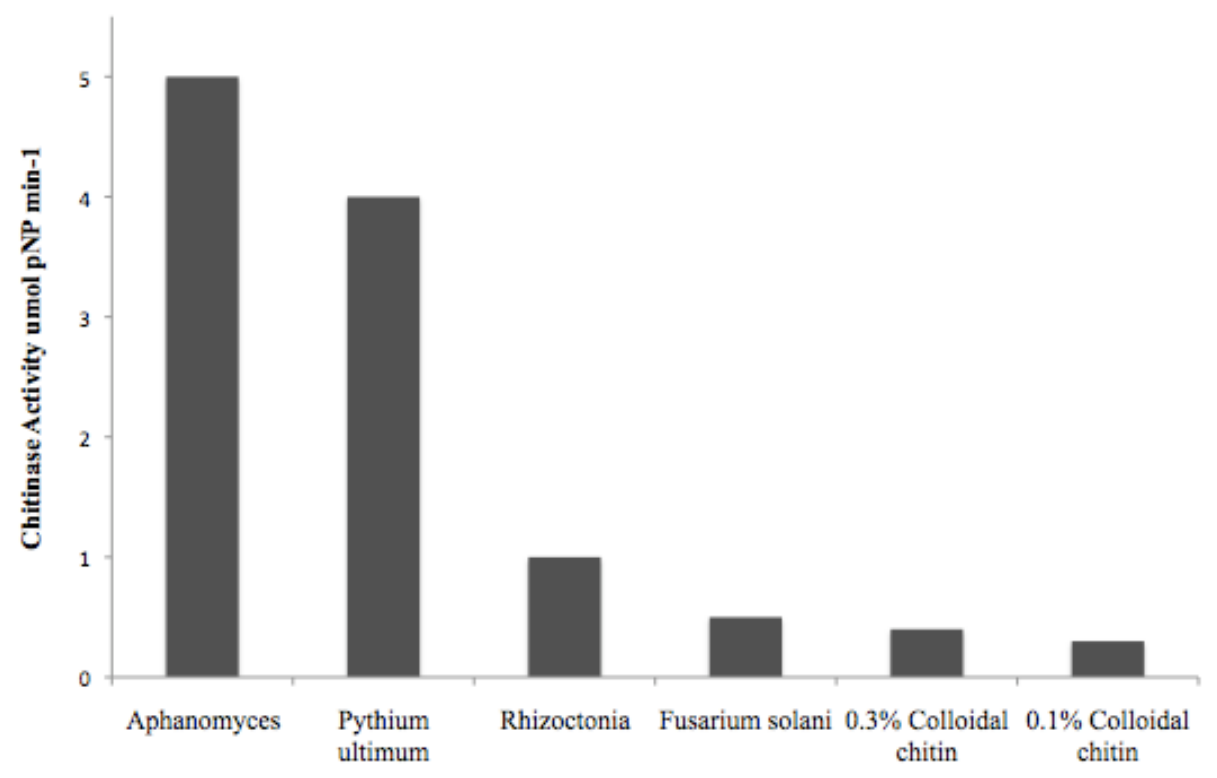

Figure 2-1. Production of S. lydicus chitinase on mixed substrate containing 3:1 colloidal chitin and chitin derived from different fungal cell walls (reproduced from Mahadevan and Crawford, 1997). 
potential to be a successful biocontrol agent (Mahadevan and Crawford, 1997). It is particularly active against oomycete fungi (Tokala et al., 2002).

\section{Colonization of Plant Roots and Viability in the Soil}

Streptomyces lydicus WYEC108 rapidly colonized untreated pea and cotton roots, as well as sweet corn roots germinating from seeds treated with the chemical fungicides Captan, Thiram, Imazaul, and Metalaxyl, indicating that it is compatible with these fungicides. In sterile soil with Pythium oospores added after sterilization, severe seed rot and damping-off of untreated pea and cotton seeds occurred. In sterile soil treated with WYEC108, the percentages of healthy pea plants increased from $14.3 \%$ to $64.2 \%$, and the percentages of healthy cotton plants increased from $7.1 \%$ to $83.6 \%$. The ability of WYEC108 to rapidly colonize plant roots of seeds treated with WYEC108, even those treated with chemical fungicides, and decrease infection of the plants by Pythium, can contribute to the success of WYEC108 as a biocontrol agent (Yuan and Crawford, 1995).

When WYEC108 was mixed with both sterile and nonsterile soils, its population remained viable in the soil over 3.5 months. The population in sterile soil increased over the first 1.5 months, and then remained stable, while the population in nonsterile soil declined over the first 1.5 months, and then steadily increased to roughly the initial population over 2 more months. In soil amended with WYEC108, its population remained stable along the length of the roots after 30 days, but its population on roots tips was 1,000 times higher than in the subcrown in nonsterile soil. In soil without WYEC108 throughout, its population declined sharply below $3 \mathrm{~cm}$ from the top, where the formulation was applied to the seeds. Accumulation of WYEC108 at root tips may 
enhance disease control, since root tips are more vulnerable to soil borne fungal pathogens (Yuan and Crawford, 1995).

Evaluation of Streptomyces lydicus as a Fungal Biocontrol Agent

WYEC108 has had varying levels of success as a biocontrol agent in laboratory, greenhouse, and field settings.

\section{Evaluation in the Lab}

Oomycetes are sensitive to streptomycin and other antibiotics produced by Streptomyces sp. because their cellulosic cell walls are permeable to the antibiotics. When detached leaves of Rhododendron and Camellia were treated with biocontrol agents prior to inoculation with the oomycete Phytophthora ramorum, the causal agent of sudden oak death and ramorum blight, Actinovate ${ }^{\circledR}$ (containing S. lydicus WYEC108) was intermediate in effectiveness compared to the other biocontrol agents (Table 2-2). The biocontrol agents were grown in vitro, and the fungal mycelia of all $P$. ramorum lineages were inhibited the least by Actinovate,${ }^{\circledR}$ compared to the other biocontrol agents evaluated in vitro. Actinovate ${ }^{\circledR}$ was compatible with the Bacillus spp. and Trichoderma spp. biocontrol agents evaluated. The inability of the WYEC108 formulation and other biocontrol formulations to adequately control P. ramorum suggests that they are not

Table 2-2. Commercial biocontrol products used in a study against Phytophthora ramorum, the causal agent of sudden oak death and ramorum blight (adapted from Elliott et al., 2009).

\begin{tabular}{ll}
\hline Name & Organism \\
\hline Serenade $^{\circledR}$ & Bacillus subtilis QST 713 \\
Companion $^{\circledR}$ & Bacillus subtilis GB03, other B. subtilis, B. lichenformis, B. Niegaterium \\
Actinovate $^{\circledR}$ & Streptomyces lydicus WYEC108 \\
Plant Helper $^{\circledR}$ & Trichoderma atroviride CHS 861 \\
Soilgard $^{\mathrm{TM}}$ & Gliocladium virens strain GL-21 \\
\hline
\end{tabular}


suitable for this use. However, the compatibility of the WYEC108 formulation with other biocontrol agents suggests that it may be suitable for use with other biocontrol agents in use against other fungal pathogens (Elliott et al., 2009).

\section{Evaluation in the Greenhouse}

Damping-off of chickpea can be caused by the oomycete Pythium ultimum. When chickpea seeds were treated with the biocontrol agents Baccilus pumilus, B. subtilis GB03, B. subtilis MBI 600, S. lydicus WYEC108, S. griseoviridis, or Trichoderma harzianum, the biocontrol agents did not control damping-off. WYEC108 and B. pumilus had no effect on emergence, while the other biocontrols decreased percent emergence of chickpeas planted in steam-sterilized soil (Leisso et al., 2009). This suggests that WYEC108 is not suitable as a biocontrol agent against fungal pathogens of chickpea when used alone. However, there may be potential for its use as a biocontrol agent in combination with other biocontrols or fungicides since it has been compatible with them in other trials.

In soil with oospores of $P$. ultimum and A. euteiches added, pea, cotton, and sweet corn seeds coated with WYEC108 were 2.5 and 8 times less infected than untreated controls, without or with preincubation, respectively. Coating cotton, pea, and sweet corn seeds with WYEC108 spores and mycelia greatly reduced Pythium infection of the germinating seeds. After 48 hours, less than 70\% of seeds coated with WYEC108 spores or mycelia were infected, compared to $100 \%$ of uncoated seeds. Seeds were better protected when coated 24 hours prior to planting (Yuan and Crawford, 1995).

Integrating biocontrols with chemical fungicides has become an acceptable strategy for pest systems, in order to reduce the chemicals used and improve plant 
quality. However, biocontrol agents have had less success controlling Fusarium wilt in cyclamen than chemical fungicides (Minuto et al., 1995). To determine whether biocontrols could prevent Fusarium wilt in cyclamen when applied at transplanting, plants were treated with a biocontrol one day after transplanting, and inoculated seven days after treatment. Biocontrols tested were Actinovate ${ }^{\circledR}($ S. lydicus WYEC108), Companion ${ }^{\circledR}\left(\right.$ B. subtilis GB03), Deny ${ }^{\circledR}\left(\right.$ Burkholderia cepacia, type WI), MycoStop ${ }^{\circledR}$ (S. griseoviridis K61), and PlantShield ${ }^{\circledR}$ (T. harzianum T-22). All plants were then treated with a chemical fungicide 14 and 28 days after planting. The biocontrols delayed the onset of disease symptoms, but did not suppress the total amount of disease progress compared to the control, showing limited success of all the biocontrols tested, including WYEC108 (Elmer and McGovern, 2004).

Different combinations of biocontrol organisms and chemicals vary in their effectiveness against Fusarium wilt. To evaluate the efficacy of drenching cyclamen plants with biocontrols after a preventive chemical treatment, plants were first treated with a chemical, and later treated with a biocontrol agent, and then inoculated. All treatments that included thiophanate methyl and a biocontrol reduced disease progress, while thiophanate methyl alone did not. In reducing the percentage of vascular discoloration, Actinovate ${ }^{\circledR}$ was compatible with thiophanate methyl, but not with Fludioxonil. WYEC108 and the other biocontrol agents reduced disease progress when used in combination with chemical fungicides (Elmer and McGovern, 2004).

To evaluate the efficacy of tank-mixing chemicals with biocontrols, combinations were applied to plants that had been previously inoculated. The first treatment consisted of Azoxystrobin or Fludioxonil, combined with either Actinovate, ${ }^{\circledR}$ PlantShield, ${ }^{\circledR}$ or no 
biocontrol. The second treatment consisted of either no treatment, Actinovate, ${ }^{\circledR}$ PlantShield, ${ }^{\circledR}$ Azoxystrobin, or Fludioxonil. Disease progress was reduced the most when Actinovate ${ }^{\circledR}$ was tank-mixed with Fludioxonil and followed by Actinovate ${ }^{\circledR}$.

Streptomyces lydicus WYEC108 had varying success at reducing disease progress of Fusarium wilt of cyclamen when used with different timing and in combination with different biocontrol agents and chemical fungicides (Elmer and McGovern, 2004).

\section{Evaluation in the Field}

The effectiveness of Actinovate ${ }^{\circledR}$ and Kaligreen ${ }^{\circledR}$, an organically certified fungicide based on potassium bicarbonate, and the conventional fungicide Procure ${ }^{\circledR}$ (triflumizole) at controlling powdery mildew of cantaloupe (caused by Podosphaera xanthii) were evaluated in a field trial in Yuma, AZ. The fungicides were applied alone or within a rotational program. Foliar treatments were made three or five times over a one month period. A high level of powdery mildew developed on untreated plants by crop maturity (25-50\% coverage of leaves). Five treatments of Procure ${ }^{\circledR}$ resulted in $100 \%$ control of the disease, five treatments of Actinovate ${ }^{\circledR}$ resulted in $72 \%$ reduction of powdery mildew, and five treatment of Kaligreen ${ }^{\circledR}$ resulted in $59 \%$ reduction. Three treatments of Procure ${ }^{\circledR}$ resulted in $79 \%$ disease reduction, while three treatments of Procure ${ }^{\circledR}$ supplemented with two treatments of Actinovate ${ }^{\circledR}$ or Kaligreen ${ }^{\circledR}$ resulted in $82 \%$ and $85 \%$ reduction, respectively. Three treatments of Actinovate ${ }^{\circledR}$ supplemented with two treatments of Kaligreen ${ }^{\circledR}$ resulted in $79 \%$ disease reduction. No significant differences in yield of marketable melons occurred among different treatments. Five applications of Actinovate ${ }^{\circledR}$ provided adequate powdery mildew suppression for commercial growers. Treatment programs integrating two applications of either 
biocontrol product with three Procure ${ }^{\circledR}$ applications provided even better powdery mildew suppression, at a level that would be considered adequate by many to most melon growers in AZ. Applied alone, Actinovate ${ }^{\circledR}$ can provide adequate powdery mildew suppression for many commercial growers (Matheron and Porchas, 2008).

Evaluation of Trichoderma harzianum and Streptomyces lydicus as plant growth promoting organisms

Plant growth promotion by microorganisms can be due to inhibition and alteration of the rhizosphere bacteria, the manufacture of growth-stimulating substances like hormones, or stimulation of nutrient uptake and improvement of nutrient availability (Celar and Valic, 2005). The mechanisms by which T. harzianum and S. lydicus act as plant growth promoters and the capability of those mechanisms to improve plant growth will be discussed in this section.

\section{Trichoderma harzianum as a Plant Growth Promoter}

Some strains of Trichoderma have increased plant growth, even in the absence of pathogens. Some plant responses to Trichoderma have included faster germination, increased percentage germination, and increased plant height, leaf area, and dry weight. Trichoderma harzianum was studied to determine whether it secretes in vitro growthregulating substances capable of increasing plant germination rate and percentage, independent of plant presence. Solutions of T. harzianum mycelia were created, and then filtered to remove mycelia after 10 days. The culture filtrate of $T$. harzianum stimulated the initial germination of tomato seeds, but did not influence the final number of germinated seeds. Inhibition or stimulation of germination may be related to the substances regulating the ratio between gibberellins and abscisic acid. The earlier 
germination of seeds can increase plant height and weight after a certain time, especially in short-duration experiments, where germinating 2-3 days earlier can represent $10 \%$ of the growing period. This should be taken into account in the interpretation of results (Celar and Valic, 2005).

The plant growth promoting activity of Rootshield ${ }^{\circledR}$ on tomato plants was studied in Italy. With $3 \times 10^{6} \mathrm{CFU} \mathrm{ml} \mathrm{soil}{ }^{-1}$, Rootshield ${ }^{\circledR}$ did not significantly increase the plant height or biomass (39.1 cm height, $29.3 \mathrm{~g}$ biomass) compared to untreated plants (38.4 $\mathrm{cm}$ height. $27.9 \mathrm{~g}$ biomass) in the absence of plant pathogens (Srinivasan et al., 2009). Trichoderma harzianum has increased the germination rate of tomato seeds, and may be able to increase plant height and biomass by stimulating earlier germination (Celar and Valic, 2005).

\section{Streptomyces lydicus as a Plant Growth Promoter}

Streptomyces lydicus WYEC 108 has improved plant growth and crop yield, in lab and greenhouse studies, with several plant species. The benefits to the plants are independent of biocontrol properties, as they occurred in the absence of fungal plant pathogens. One of its primary beneficial activities is the production of extracellular siderophores which help the plants they colonize to take up iron from the soil more effectively. Although iron is usually abundant in soil, it occurs in highly insoluble forms at neutral or alkaline $\mathrm{pH}$ and in aerobic conditions (Salove, 2002).

Radishes were grown in a greenhouse in nonsterile soil free of pathogens. Carrots were germinated and grown aseptically in vitro in a plant growth chamber. Surfacesterilized radish or carrot seeds were inoculated with $0.1 \mathrm{~g}$ of a formulation containing spores of S. lydicus WYEC 108 in sterile, dry talc, with 1 X $10^{8}$ colony-forming units per 
gram. The control was treated with only sterile talc. The seeds were grown individually in pots for 30 days. At harvest, radishes grown in the greenhouse with S. lydicus WYEC 108 had an average weight approximately $8.4 \%$ greater than those of the control. At harvest, carrot seedlings treated with S. lydicus WYEC 108 had an average 17.3\% higher weight than the controls (Salove, 2002).

Siderophore production in the rhizosphere is likely one of the key mechanisms by which these strains improve plant growth. S. lydicus WYEC 108 produces hydroxamatetype siderophores, which likely contributed to the observed plant growth stimulation. Siderophore production is repressed with soil $\mathrm{Fe}^{3+}$ concentrations higher than $50 \mu \mathrm{M}$. (Salove, 2002). S. lydicus WYEC 108 may also produce other plant-growth promoting metabolites in the rhizosphere (Tokala et al., 2002).

When the vegetative hyphae of $S$. lydicus WYEC 108 colonize the roots of young pea (Pisum sativum) seedlings, they also colonize the surface of emerging nodules and sporulate within root surface cell layers. The S. lydicus develops a beneficial symbiotic relationship with the nodule bacteria, wherein the actinomycete promotes nodulation, enhances nodule growth, and aids the nodule bacteria in assimilating iron from the soil, resulting in enhanced overall growth of the plant (Tokala et al., 2002).

Pea plants inoculated with S. lydicus WYEC 108 had significantly longer shoots, higher average plant and root weights, higher average nodule weight, and higher average nitrogenase activities compared to the uninoculated plants. Not only were the nodules larger, but there were greater numbers of bacteroids in the nodules of the inoculated plants, and the bacteroids in the inoculated plants had elevated Fe and Mo levels, indicating greater vigor, possibly due to siderophore production by the S. lydicus (Tokala 
et al., 2002). S. lydicus WYEC 108 has increased plant height and weight in radish, carrot, and pea plants, and has increased nodulation in pea plants.

\section{Benefits of Grower Involvement in Disease Control Experiments}

Research involving growers can lead to better plant disease management by encouraging local experimentation and knowledge sharing, and making sure that researchers' work is relevant to growers' needs and conditions (Hasna et al., 2009).

A participatory research group consisting of tomato growers in nine organic farms in central Sweden, working with researchers and extension workers, was formed to study several possible organic methods of controlling corky root disease in tomatoes. In the evaluation after the experiments were completed, growers were asked to respond to questions by making a tick on a scale of 1 to 5 , where 1 is very negative and 5 is very positive. All responses were positive, from 3.5 to 5 , and the growers were all very receptive to participating in a new project. The growers felt that the information they learned from the project worked out well, that their participation was valuable, and that they would consider participating in another similar project. They also said that they liked being able to exchange information on corky root disease with each other and the researchers (Hasna et al., 2009).

In addition to involving growers in experiments, it is important to take into account the actual equipment used by growers for fungicide application. Fungicide drift from spray applications may influence disease development in adjacent treatment rows. Spray drift of fungicides applied to tomatoes for the control of early blight into adjacent plot areas by three different sprayers was evaluated in Ohio. In the field experiment, each plot consisted of a single row $143 \mathrm{~m}$ long, bordered on each side by one nonsprayed row. 
Plants were $30 \mathrm{~cm}$ apart in the row. Canopy height averaged $60 \mathrm{~cm}$ at maturity. All three sprayers were tractor-mounted, and delivered the chemical fungicide, Ridomil ${ }^{\circledR}$ from above the plants. Water-sensitive spray cards were placed on three metal stands downwind at the time of application at heights of 0,19 , and $25 \mathrm{~cm}$. There was a significant interaction between the type of sprayer used, downwind distance, and height of the spray cards. All of the sprayers produced enough drift to significantly affect yields in neighboring rows. Small-plot pesticide trials must utilize adequate space and buffer rows to reduce drift, and researchers should consider the use and operation of spray application machinery (Reed et al., 1993).

It is important for researchers to take their target audience into account in the design and execution of experiments to ensure that the results are applicable to real farming practices. Involving growers in the process increases the flow of information between growers and researchers, ensuring that research is appropriate and useful to growers.

\section{Summary}

Biological control agents are growing in popularity due to environmental and health concerns over using chemical fungicides. Many microorganisms have been studied and developed into commercially available formulations to control fungal plant pathogens of tomato. Target diseases include corky root rot, damping-off, early blight, sclerotinia, Fusarium wilt, Verticillium wilt, and powdery mildew.

Trichoderma harzianum competes with fungal plant pathogens for space and nutrients, is mycoparasitic, suppresses pathogens' hydrolytic enzymes, and induces host resistance. Trichoderma harzianum may perform better in nutrient-rich soils, and has 
reduced corky root disease, Fusarium wilt, and damping-off in tomato in lab and greenhouse settings.

Streptomyces lydicus WYEC108 is an antagonist of fungal plant pathogens, through many different modes of action. It excretes antifungal compounds, including antibiotics, to cause local death or inhibition of fungal mycelia. It also produces extracellular chitinase to control fungal root and seed diseases. This chitinase production can be induced with low levels of chitin, especially that of fungal cell walls, but repressed by the presence of sugars. WYEC108 can rapidly colonize plant roots, especially at root tips, and remain viable in the soil for over 3.5 months.

Using biocontrols or integrating biocontrols with chemical fungicides can reduce chemical use and improve plant quality. Different combinations of WYEC108, chemicals, and application times have varying success against fungal pathogens. WYEC108 acts differently in field trials than in laboratory settings. Because WYEC108 reacts differently with each fungal pathogen, crop, and field, it is important to evaluate its effectiveness under similar conditions to those encountered by agricultural producers to predict its success. Research is needed to evaluate the ability of Actinovate ${ }^{\circledR}$ to control fungal plant pathogens of tomato.

In the absence of plant pathogens, some strains of Trichoderma have increased plant germination rate, increased percentage germination, and increased plant height, leaf area, and dry weight. However, tomato height and biomass were not significantly increased by the application of Rootshield ${ }^{\circledR}$. Through the production of siderophores and possibly other plant-growth promoting metabolites in the rhizosphere, S. lydicus WYEC 
108 has increased plant height and weight in radish, carrot, and pea plants, and has increased nodulation in pea plants.

Researchers and growers can benefit from the enhanced information exchange attained by involving growers in the experimental process. Doing so can lead to more useful and applicable results, and lead to better plant disease management by encouraging local experimentation and knowledge sharing. 


\section{CHAPTER 3}

\section{Scope}

The collection of tomato quality and yield during harvests was conducted over approximately 10 weeks, between 1 September and 12 November 2010. Data collection pertaining to germination, height, root mass, and the presence of disease was conducted between 12 February and 2 November 2010.

The geographic location of the greenhouse trial was the Greenheart Nursery in Arroyo Grande, and the field study was 0.5 acre of land near the town of Los Alamos in Santa Barbara County, California.

The treatment variables in the greenhouse consisted of two treatments: 1) one initial Actinovate $^{\circledR}$ treatment, and 2) one initial RootShield $^{\circledR}$ treatment. The treatment variables in the field trial consisted of four treatments: 1) one initial Actinovate ${ }^{\circledR}$

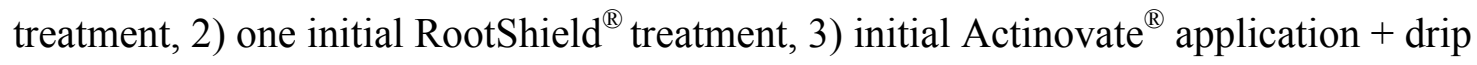
applications, and 4) initial Actinovate ${ }^{\circledR}$ application + drip applications + foliar applications.

The response variables in the greenhouse study consisted of four responses: 1) percent germination, 2) percent survival, 3) plant height, and 4) root and shoot weight. The response variables in the field trial consisted of five responses: 1) Plant height, 2) Quality (percentage of marketable tomatoes), 3) Yield, and 4) disease presence (\% of total plant leaf area showing symptoms). 
Methods and Materials

\section{Greenhouse}

Tomato seeds (Solanum lycopersicum cv. Cherokee Purple) were sown by hand in 231-hole plastic plug trays in Greenheart Nursery in Arroyo Grande on 16 January 2010. They were sown into a mixture of cocoa fiber, gypsum, dolomite, Aqua-Gro ${ }^{\circledR}$ (a surfactant), and a proprietary mixture of fertilizers approved for use in organic production by the Organic Materials Review Institute (OMRI). Seeds were then covered with vermiculite and drenched with the manufacturer recommended rate of RootShield ${ }^{\circledR}(880$ seeds in four trays), or Actinovate ${ }^{\circledR}$ (2079 seeds in nine trays).

Seedlings were treated over the duration of the greenhouse experiment with products approved for organic production by OMRI per Greenheart Nursery's regimen to control plant diseases in their organic greenhouses (Table 3-1). The objectives of the greenhouse portion of the study involved evaluating the plant growth-promoting effects of Actinovate ${ }^{\circledR}$ on tomato plants in the absence of fungal pathogens, and other fungicides applied should not have influenced plant growth.

Table 3-1. Fertilizer, fungicide, and insecticide applications in the organic greenhouse.

\begin{tabular}{|c|c|c|c|}
\hline Date & Product & Product type & Active ingredient(s) \\
\hline Feb 8 & MilStop $^{(R)}$ & Broad spectrum foliar fungicide & Potassium bicarbonate \\
\hline Feb 8 & Cease $^{\mathrm{TM}}$ & Broad spectrum foliar fungicide & Bacillus subtilis \\
\hline Feb 11 & True $^{\circledR} 4-0-2$ & Fertilizer & Fish-based \\
\hline Feb 12 & Cueva $^{\mathrm{TM}}$ & Broad spectrum foliar fungicide & Copper Octanoate \\
\hline Feb 17 & Trilogy $^{\circledR}$ & Fungicide/miticide/insecticide & Hydrophobic Neem oil extract \\
\hline Mar 2 & PyGanic $^{\circledR}$ & Insecticide dust & Pyrethrins \\
\hline Mar 17 & Cease $^{\mathrm{TM}}$ & Broad spectrum foliar fungicide & Bacillus subtilis \\
\hline Mar 18 & Cueva $^{\mathrm{TM}}$ & Broad spectrum foliar fungicide & Copper Octanoate \\
\hline
\end{tabular}

Ungerminated seeds were counted four weeks after sowing. Seedling shoot and root samples were collected for weighing and measuring from each of the two treatments 
on 26 March 2010 (ten weeks after sowing). One to three seedlings were collected from plug trays near the center of each tray, for a total of 10 samples per treatment. Seedlings were pulled, and the soil was rinsed off the roots with tap water, and the roots were dried with paper towels. Plant height was measured from the soil line to the tip of the apical meristem. The shoots and roots were dried in an oven at $55^{\circ} \mathrm{C}$ for $24 \mathrm{~h}$.

Seedling survival was calculated on 14 April 2010 (eleven weeks after sowing) by counting the total number of seedlings not surviving in each treatment, subtracting that number from the number planted, and dividing the number of surviving seedlings by the total number planted for each treatment.

Field

The field experiment was conducted on 0.5 acres of land in Santa Barbara County, California, approximately 7 miles West of Los Alamos off of Highway 135 (Fig. 3-1). The field soil is a sandy loam, mapped as the San Andreas-Tierra complex, 9 to 45 percent slopes, severely eroded. San Andreas soils are coarse-loamy, mixed, superactive, thermic Typic Haploxerolls. Tierra soils are fine, smectitic, thermic Mollic Palexeralfs. The slope was 4 percent. The field was put into production for this experiment. Previously, it served as a parking lot for field workers. The surrounding fields were farmed over the previous 5 years, with strawberries and rotating vegetable crops,

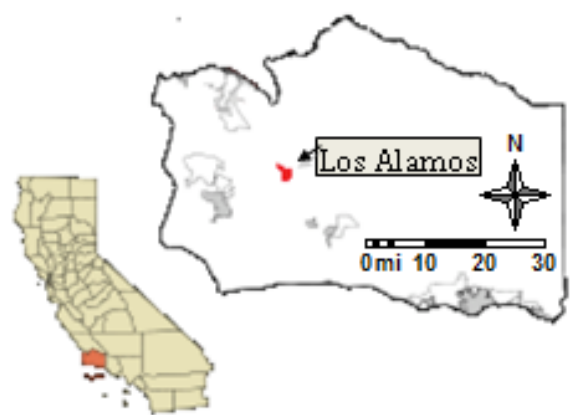

Figure 3-1. The town of Los Alamos, in Santa Barbara County, CA 
including tomato, pepper, brussels sprouts, cauliflower, broccoli, and others. The vegetables were grown with minimal inputs of pesticides and fertilizers for the previous two years, but were not certified organic.

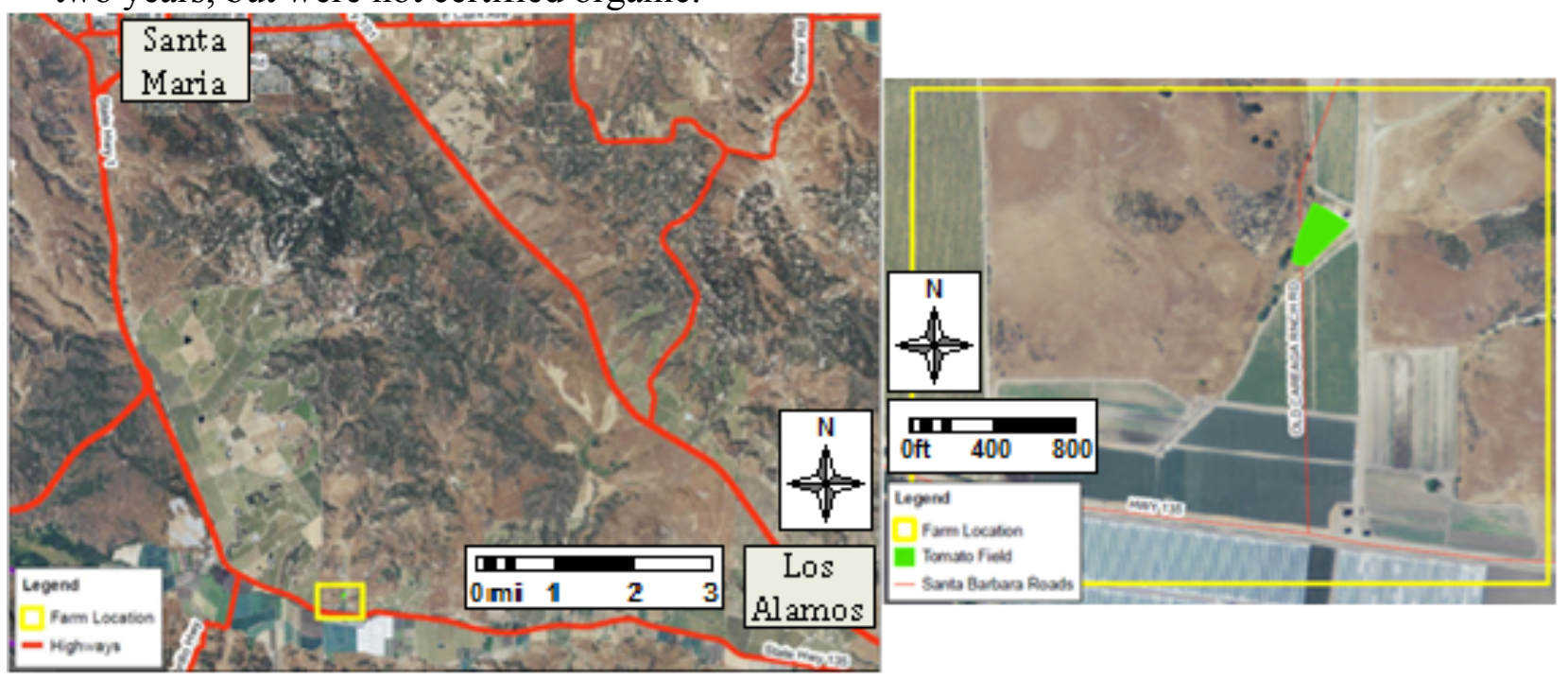

Figure 3-2. General location of the farm where the trial was conducted, outlined in yellow (Left). Location of one acre tomato field trial, in green (Right).

According to the grower, nearby fields with tomatoes (cv. Roma) grown the previous year experienced yield losses due to early blight and Phytophthora. Leaf samples collected from the Roma tomatoes grown the previous season were confirmed in a lab to have Alternaria solani, the causal agent of early blight. Spores of the fungal pathogen were first isolated from the surface sterilized leaf samples. The leaf samples were submerged in a 10\% bleach solution for 30 seconds, rinsed with tap water, and then blotted dry with a paper towel. The plant tissue was then grown in petri dishes on water agar for one week at room temperature under flourescent lights. After one week, a solution with a concentration of approximately $1.2 \times 10^{4}$ spores $\mathrm{ml}^{-1}$ Alternaria solani spores was made, using a hemacytometer to estimate the spore concentration, and using $0.05 \%$ Tween20 as the liquid. When a variety pack of healthy tomatoes (cv. Better Boy, 
Early Girl, Beefmaster, Cherry Red, Celebrity, and Roma) was inoculated with the spores, the plants showed symptoms of early blight one week later. Alternaria solani spores were isolated from the diseased plants by surface-sterilizing pieces of the newly infected tissues using the method described above, and grown in petri dishes on water agar for one week as described above.

The tomato seedlings grown in Greenheart Nursery during the first part of the study were transplanted into the prepared field by hand on 14 April 2010, approximately 12 weeks after sowing. They were planted approximately $50 \mathrm{~cm}$ apart with $2 \mathrm{~m}$ between rows. Tomato plants were irrigated as needed, approximately twice per week, by the grower, through flexible drip tape. Weeds were controlled using a cultivator between rows, and by hand between plants in each row. Tomatoes were pruned, staked, and trellised to maintain upright growth habit. Early flowers and lower leaves were routinely removed by workers to encourage vegetative growth until 1 June 2010 . Fertilizers and insecticides were applied when needed by the grower throughout the duration of the field trial (Table 3-2).

Table 3-2. Fertilizer and insecticide applications through drip tape during the field trial.

\begin{tabular}{|c|c|c|c|}
\hline $\begin{array}{l}\text { Date } \\
\text { Applied }\end{array}$ & Product & $\begin{array}{l}\text { Product } \\
\text { type }\end{array}$ & Active Ingredient(s) \\
\hline June 5 & $\begin{array}{l}\text { Biosynergizer }{ }^{\mathrm{TM}} \\
8-10-5\end{array}$ & $\begin{array}{l}\text { Liquid } \\
\text { fertilizer }\end{array}$ & $\begin{array}{l}\text { Ammonium phosphate, } \mathrm{K} \text { phosphate, } \mathrm{K} \\
\text { polyphosphate, } \mathrm{Fe}, \mathrm{Mn} \text {, and } \mathrm{Zn} \text { citrates, } \\
\text { leonardite, and fermentation by-products. }\end{array}$ \\
\hline June 2 & Admire $^{\circledR}$ & insecticide & $\begin{array}{l}\text { Imidacloprid, 1-[(6-Chloro-3-pyridinyl) } \\
\text { methyl]- } N \text {-nitro-2-imidazolidinimine }\end{array}$ \\
\hline June 21 & Biosynergizer $^{\mathrm{TM}}$ & & \\
\hline June 25 & Biosynergizer ${ }^{\mathrm{TM}}$ & Liquid & Ammonium phosphate, $K$ phosphate, $K$ \\
\hline July 3 & Biosynergizer $^{\mathrm{TM}}$ & fertilizer & porypnospnate, $\mathrm{Fe}, \mathrm{IMn}$, and $\mathrm{Zn}$ citrates, \\
\hline July 21 & Biosynergizer $^{\mathrm{TM}}$ & & \\
\hline August 3 & Thiocal $^{\circledR}$ & $\begin{array}{l}\text { soluble } \mathrm{Ca} \\
\text { and } \mathrm{S}\end{array}$ & Calcium thiosulfate \\
\hline $\begin{array}{l}\text { August } \\
26\end{array}$ & Thiocal $^{\circledR}$ & $\begin{array}{l}\text { soluble } \mathrm{Ca} \\
\text { and } \mathrm{S}\end{array}$ & Calcium thiosulfate \\
\hline
\end{tabular}


Field Data Collection

\section{Plant Height}

Plant height $(\mathrm{cm})$ was measured from the ground to the apical meristem using a flexible measuring tape every 5 to 10 days from 22 May - 1 August 2010. The height of each living plant in each plot was measured, and the median height for the plot was recorded.

\section{Yield}

Tomatoes were harvested from marked trial plots approximately once per week during the harvest period, 1 September 2010 through 12 November 2010. All ripe tomatoes in each plot were picked and separated into marketable quality or cull by field workers experienced at picking tomatoes and familiar with the fruit quality acceptable for fresh market tomatoes. Field workers did not know which plots received the different treatments. Marketable and cull tomatoes from each sample plot were weighed, counted, and recorded in the field on each harvest day.

\section{Disease Incidence}

Disease incidence and severity were assessed once every approximately $8-12$ days from 29 June through 11 November 2010 by visually inspecting the first live plant in each plot for any foliar, stem, or collar symptoms of fungal diseases. The percentage of total plant leaf area showing fungal disease symptoms was estimated, and recorded using an empirical scale of 0 to 6 (Table 3-3). 
Table 3-3. Empirical scales used to record fungal disease symptoms and plant vigor.

\begin{tabular}{|c|c|c|c|}
\hline $\begin{array}{l}\text { Disease } \\
\text { Grade }\end{array}$ & $\begin{array}{l}\text { Percent total plant leaf area } \\
\text { with disease symptoms }\end{array}$ & $\begin{array}{l}\text { Vigor } \\
\text { Grade }\end{array}$ & Plant vigor description \\
\hline 0 & None & 1 & Plant is very vigorous/healthy \\
\hline 1 & $<1$ & 2 & $\begin{array}{l}\text { Plant health has declined (ex: dull/ } \\
\text { wilted/discolored/curled/dropped } \\
\text { leaves) }\end{array}$ \\
\hline 2 & $1-<5$ & 3 & Plant health has declined greatly \\
\hline 3 & $5-<10$ & 4 & Plant appears to be near death \\
\hline 4 & $10-<15$ & 5 & Plant is dead \\
\hline 5 & $15-<30$ & & \\
\hline 6 & $>30$ & & \\
\hline
\end{tabular}

After the last tomato fruit harvest, plant stem (approximately $15 \mathrm{~cm}$ ) and root (approximately $20 \mathrm{~cm}$ ) samples were collected using a shovel and pruning shears on 19 November 2010. Three samples were collected from each treatment row, from within the field trial plots. The vascular tissue of each sample was inspected in the lab for discoloration and other disease symptoms. Four thin pieces of vascular tissue approximately $10 \mathrm{~mm}$ long x $5 \mathrm{~mm}$ wide were collected from each discolored vascular tissue sample. The pieces of vascular tissue were surface sterilized by submerging them in a $10 \%$ bleach solution for one minute, rinsing them thoroughly with tap water, and blotting them with a paper towel. The pieces of vascular tissue were then put onto water agar in petri dishes and incubated at room temperature. After seven days, the petri dishes were examined using a microscope for the presence of fungal plant pathogens.

\section{Laboratory}

Samples of suspected diseased foliar tissue collected in the field were taken to the lab for further analysis throughout the period of recording disease incidence. The presence or absence of fungal pathogens was determined by placing surface-sterilized 
tissues on water agar, allowing fungal colonies to grow, and identifying fungi using a dissecting or compound microscope.

After the conclusion of the harvest period, tomato stem and root samples were analyzed in the lab for soil borne fungal pathogens as described above in the disease incidence section.

\section{Statistical Design}

The field experiment had a randomized block design with four treatments with three replications. Each treatment was assigned a code (Table 3-1). Each of eighteen rows of tomato plants covering one acre were treated with one of four treatments. The eighteen rows of tomatoes were blocked, and rows within blocks were assigned randomly to receive treatments within each block with the constraint that buffer treatment rows occurred on each side of rows receiving foliar applications of the biocontrol.

Table 3-4. Treatments and treatment codes.

\begin{tabular}{ll}
\hline AD & Initial Actinovate ${ }^{\circledR}$ application (when sown) + drip applications \\
ADF & Initial Actinovate ${ }^{\circledR}$ application (when sown) + drip applications + foliar \\
& applications \\
A & Initial treatment with Actinovate ${ }^{\circledR}$ at time of sowing \\
R & Initial treatment with RootShield ${ }^{\circledR}$ at time of sowing \\
\hline
\end{tabular}

For the AD treatment, Actinovate ${ }^{\circledR}$ was applied to the soil through the irrigation drip tape at a rate of $12 \mathrm{oz}$ per acre for the first application, and at a rate of $6 \mathrm{oz}$ per acre every two weeks thereafter. For the ADF treatment, Actinovate ${ }^{\circledR}$ was applied to the foliage using a hand held sprayer hose connected to a tank once each week at a rate of 6 oz per acre, in addition to the drip application described for the AD treatment. 
For the drip applications, a valve was installed at the head of each row of tomatoes, allowing the flow of water to any row to be cut off. When Actinovate ${ }^{\mathbb{R}}$ was applied through the irrigation lines, the entire field was first irrigated for 60 min while 2 oz of Actinovate ${ }^{\circledR}$ was mixed with water in a tank with 2 oz of the surfactant Aero Dyne$\mathrm{Amic}^{\circledR}$ (organosilicon). Next, the valves were closed for all of the A, R, and buffer rows until all of the Actinovate ${ }^{\circledR}$ in the tank was applied to the AD and ADF rows (30 min). After applying the Actinovate ${ }^{\circledR}$ for 30 min, the $\mathrm{AD}$ and $\mathrm{ADF}$ rows were irrigated with water for 30 min to flush the irrigation system to keep it from plugging. The rows not treated with Actinovate ${ }^{\circledR}$ were irrigated for an additional 60 min afterward, with the valves to the $\mathrm{AD}$ and $\mathrm{ADF}$ rows closed. Using this method, each row was irrigated for 120 min total.

The tomatoes with $\mathrm{A}$ and $\mathrm{R}$ treatments did not receive any fungicide applications over the course of the field experiment. The buffer rows on either side of the ADF treatment did not receive any additional fungicide applications over the course of the experiment. Since the commercial nursery growing the seedlings uses only Rootshield ${ }^{\circledR}$ as a soil drench, and the grower does not normally use any inputs to control fungal plant pathogens, the R treatment served as the control.

Wooden stakes were installed after every three plants in each row. Plots consisting of three plants each were assigned after every nine plants to be sampled for plant height, fruit quality, and fruit yield measurements (Appendix A). On the day pltos were designated, sets of three plants where any of the plants were dead or missing were not designated as plots. Ten sampling plots were chosen in each row in the first block (rows $3,4,6$, and 8), thirteen plots per row in the second block (rows 9, 10, 12, and 14), 
and eight plots per row in the third block (rows 15, 16, 18, and 20), due to differences in row lengths among the replications. Each plot ( 3 plants) made up one experimental unit. Each plot consisted of three neighboring tomato plants in a row, bordered on either side with supporting wooden stakes. Sampling plots were flagged with fluorescent pink ribbon, and harvest crews were instructed not to pick tomatoes in the flagged plots while harvesting fruit to sell.

The stakes and ribbon around each plot were marked with a unique plot number, with the first part representing the row number from $3-20$, and the second part representing the position in the row from north to south, starting with 1 (Fig. 3-2).

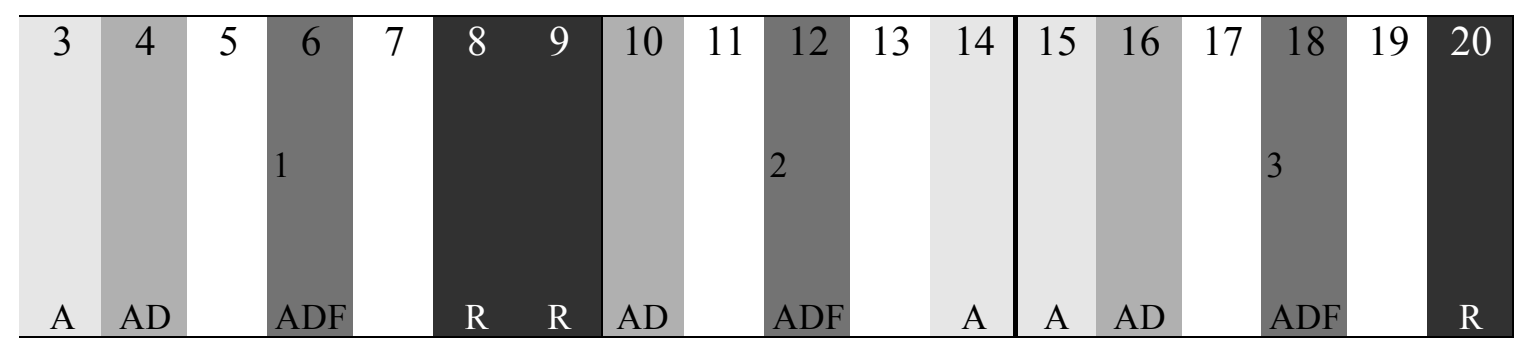

Figure 3-3. 18 rows of tomatoes split into 3 blocks with row numbers at top, block numbers center, and treatment codes at bottom. Rows with no specified treatments were buffers for foliar application drift, with no data collected from them.

\section{Quality Control}

An irrigation evaluation was performed on 26 May 2010 using catch cans. The distribution uniformity of the irrigation system was $89 \%$, compared to the industry standard of $85 \%$ for drip irrigation, indicating that the tomatoes were all receiving relatively equal amounts of water through the drip tape.

To help account for natural variations in plant height, yield, and disease occurrence not due to the treatments applied, plant vigor was evaluated for the first live 
plant in each plot each time disease and yield observations were made. Vigor observations were made using the empirical scale previously outlined (Table 3-3). Vigor observations were compared to determine whether plant vigor was related to different areas of the field, plant height, yield, disease occurrence.

Since growing field tomatoes without any biological or chemical protection against fungal pathogens would be unrealistic compared to actual practices of tomato growers, the R treatment was used as the control.

\section{Methods of Analyzing Data}

\section{Greenhouse}

The germination rates and seedling survival rates for each treatment were compared using unpaired $t$-tests. The seedling height, fresh shoot weight, dry root weight, and dry shoot weight were also compared by performing unpaired $t$-tests using Minitab ${ }^{\circledR}$ Statistical Software (Minitab, 2010).

The sample variances for seedling germination with Actinovate $^{\circledR}$ and Rootshield $^{\circledR}$ treatments were not significantly different at $\alpha=0.05$, so the variances were pooled for the unpaired $t$-test. The sample variances for seedling survival with Actinovate $^{\circledR}$ and Rootshield $^{\circledR}$ treatments were significantly different at $\alpha=0.05$, with $\mathrm{F}_{\text {stat }}=0.14, d f_{1}=8$, $d f_{2}=3$, and $\mathrm{P}=0.025$, so the variances were not pooled during the unpaired $t$-test. The sample variances for seedling height and fresh shoot weight between the treatments were not significantly different at $\alpha=0.05$. The sample variances for root dry weight with Actinovate $^{\circledR}$ and Rootshield ${ }^{\circledR}$ treatments were significantly different at $\alpha=0.05$, with $F_{\text {stat }}$ $=0.13$, with $d f_{1}=7$ and $d f_{2}=9(\mathrm{P}=0.013)$. The sample variances for shoot dry weight with Actinovate ${ }^{\circledR}$ and Rootshield ${ }^{\circledR}$ treatments were not significantly different at $\alpha=0.05$. 


\section{Field}

The effects of treatments on plant heights were compared using repeated measures one-way ANOVA general linear model, using SPSS ${ }^{\circledR}$ Statistics software (SPSS Statistics, 2003). Height data were log-transformed prior to analysis. The effects of treatments on plant yield by weight $(\mathrm{g})$ and by number of fruits were compared using repeated measures one-way ANOVA general linear model. The effects of treatments on the marketable portion of the total number of tomatoes produced by plants were compared using repeated measures one-way ANOVA general linear model. The marketable percentage of tomatoes were arcsine transformed $(\arcsin \sqrt{ } \%)$ prior to analysis (SPSS Statistics, 2003).

The effects of treatments on the presence and extent of powdery mildew infection were compared using repeated measures one-way ANOVA general linear model. The midpoint of each disease grade was used, and data were natural log-transformed prior to analysis (SPSS Statistics, 2003). The effects of treatments on the presence of Verticillium wilt or Sclerotinia infection were compared using the Kruskal-Wallis general association test (Minitab, 2010). The effects of treatments on overall plant health, or vigor, were compared using repeated measures one-way ANOVA general linear model, and data were natural log-transformed prior to analysis. The Greenhouse - Geisser and Least Significant Difference (LSD) corrections were used for all data analyzed using the repeated measures one-way ANOVA general linear model (SPSS Statistics, 2003). 


\section{CHAPTER 4}

Results

\section{Greenhouse}

In the greenhouse, germination rate was not significantly different among seeds treated with Actinovate ${ }^{\circledR}$ and seeds treated with Rootshield ${ }^{\circledR}$ four weeks after sowing $(\mu=$ $88.89, \mathrm{~s}=0.028$ and $\mu=89.71, \mathrm{~s}=0.024$, respectively, $\mathrm{P}=0.622$ ). Seedlings in the Actinovate $^{\circledR}$ treatment appeared to be taller at four weeks, although no measurements were taken at that time. No significant difference occurred between seedling survival for seedlings treated with Actinovate ${ }^{\circledR}(\mu=86.72 \%, s=0.015)$ or Rootshield ${ }^{\circledR}(\mu=86.42 \%, s=$ 0.040) 11 weeks after sowing $(\mathrm{P}=0.892)$. Seedlings treated with Actinovate ${ }^{\circledR}$ appeared taller and brighter green compared to those treated with Rootshield ${ }^{\circledR}$, although no height or color data were collected at that time.

Seedlings treated with Actinovate ${ }^{\circledR}$ had greater average height $(17.37 \mathrm{~cm}, \mathrm{~s}=$ $2.91, \mathrm{n}=10)$ than those treated with Rootshield ${ }^{\circledR}(15.11 \mathrm{~cm}, \mathrm{~s}=1.82, \mathrm{n}=10)$ after ten weeks, although the difference was not significant at $\alpha=0.05(\mathrm{P}=0.052)$. The seedlings treated with Actinovate ${ }^{\circledR}$ were $2.25 \mathrm{~cm}$ taller on average, although the difference was not significant with a $95 \%$ confidence interval of $(-0.03,4.54)$. No significant differences were detected in the fresh shoot weights, dry root weights, or dry shoot weights for seedlings treated with Actinovate ${ }^{\circledR}$ or Rootshield ${ }^{\circledR}$ at $\mathrm{P}<0.05$. Overall, no significant differences in seedling height, fresh shoot weight, dry root weight, or dry shoot weight occurred between seedlings treated with Actinovate ${ }^{\circledR}$ and those treated with Rootshield ${ }^{\circledR}$ (Table 4-1). 
Table 4-1. Effect of drenching seeds with Actinovate ${ }^{\circledR}$ or Rootshield ${ }^{\circledR}$ at time of sowing on mean seedling height, fresh shoot weight, dry root weight, and dry shoot weight of organically grown tomato seedlings 10 weeks after sowing.

\begin{tabular}{lllll}
\hline Treatment & $\begin{array}{l}\text { Mean plant } \\
\text { height }(\mathrm{cm})\end{array}$ & $\begin{array}{l}\text { Mean fresh shoot } \\
\text { weight }(\mathrm{g})\end{array}$ & $\begin{array}{l}\text { Mean dry shoot } \\
\text { weight }(\mathrm{mg})\end{array}$ & $\begin{array}{l}\text { Mean dry root } \\
\text { weight }(\mathrm{mg})\end{array}$ \\
\hline Actinovate $^{\circledR}$ & $17.37 \pm 2.91$ & $2.15 \pm 0.82$ & $263.3 \pm 49.5$ & $52.88 \pm 5.89$ \\
Rootshield $^{\circledR}$ & $15.11 \pm 1.82$ & $2.10 \pm 0.74$ & $265.6 \pm 95.1$ & $57.20 \pm 16.3$ \\
P-value & 0.052 & 0.887 & 0.950 & 0.454 \\
$95 \% \mathrm{CI}^{*}$ & $(-0.03,4.54)$ & $(-0.68,0.78)$ & $(-81.2,76.5)$ & $(-16.59,7.94)$ \\
\hline
\end{tabular}

$* 95 \%$ Confidence intervals for the difference between means were constructed using unpaired $t$-tests.

Field

\section{Plant Height}

No significant statistical differences were found in mean plant heights for the four different treatments $(\mathrm{A}, \mathrm{AD}, \mathrm{ADF}, \mathrm{R})$ during the 10 weeks of plant measurements at $\alpha=0.05$. The treatment effect had an F statistic of 1.559 , with $P=0.20$. No significant differences occurred among mean plant height for the different treatments on specific days (Fig. 4-1).

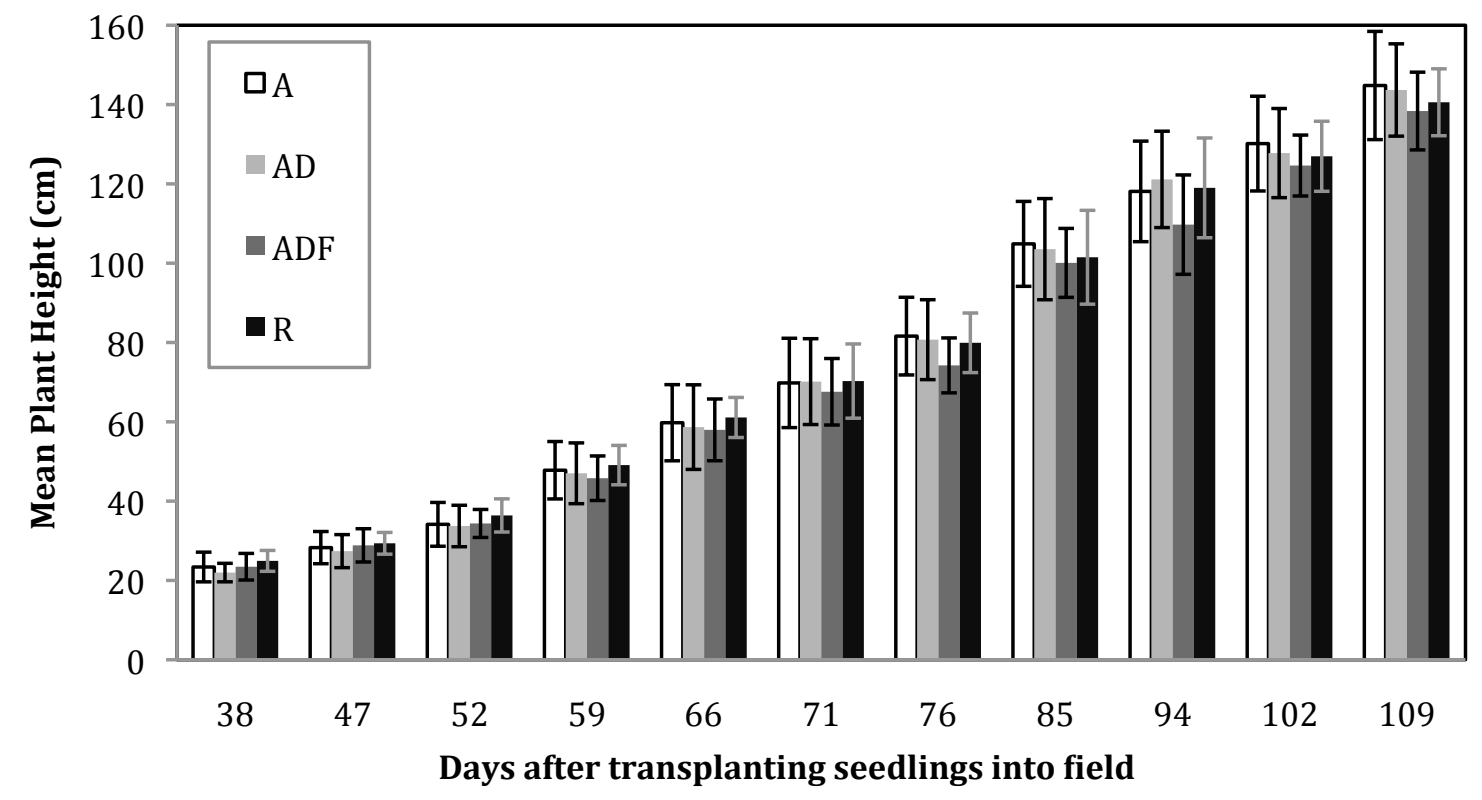

Figure 4-1. Effects of one Actinovate ${ }^{\circledR}$ application (A), repeated drip Actinovate $^{\circledR}$ applications (AD), repeated drip + foliar Actinovate ${ }^{\circledR}$ applications (ADF), and one Rootshield $^{\mathbb{B}}$ application (R) on tomato plant height 38 - 109 days after transplanting. Error bars indicate $95 \%$ Confidence Intervals. Means with overlapping error bars are not significantly different. 


\section{Yield}

\section{Marketable Fruit Weight}

The mean weights of marketable fruit per plot were significantly greater in the ADF treatment than in the A treatment overall $(\mathrm{P}=0.05)$. The mean weights of marketable fruit per plot were greater in the ADF treatment than in the R treatment, although the means were not significantly different (Table 4-2).

Table 4-2. Effect of one initial Actinovate ${ }^{\circledR}$ application at sowing (A), repeated Actinovate ${ }^{\circledR}$ applications through drip tape $(\mathrm{AD})$, repeated drip and foliar Actinovate ${ }^{\circledR}$ applications (ADF), and one initial Rootshield $\mathbb{R}$ application (R) on mean marketable yield weight.

\begin{tabular}{|c|c|c|c|c|}
\hline \multirow{2}{*}{ Treatment } & \multirow{2}{*}{ Mean Yield (g) } & \multirow{2}{*}{ Std. Error } & \multicolumn{2}{|c|}{ 95\% Confidence Interval } \\
\hline & & & Lower Bound & Upper Bound \\
\hline A & $1734 \mathrm{~b}$ & 90.0 & 1556 & 1912 \\
\hline $\mathrm{AD}$ & $1884 \mathrm{ab}$ & 90.0 & 1706 & 2062 \\
\hline ADF & $2102 \mathrm{a}$ & 90.0 & 1923 & 2280 \\
\hline $\mathrm{R}$ & $1859 \mathrm{ab}$ & 90.0 & 1681 & 2037 \\
\hline
\end{tabular}

Values followed by different letters within a column differ significantly (LSD adjustment for multiple comparisons, $\mathrm{P}<0.05$ )

A treatment effect was detected for mean weight of marketable fruit on several specific harvest days $(\mathrm{P}=0.01)$, but no clear trend was observed for the differences (Fig. 4-2). 


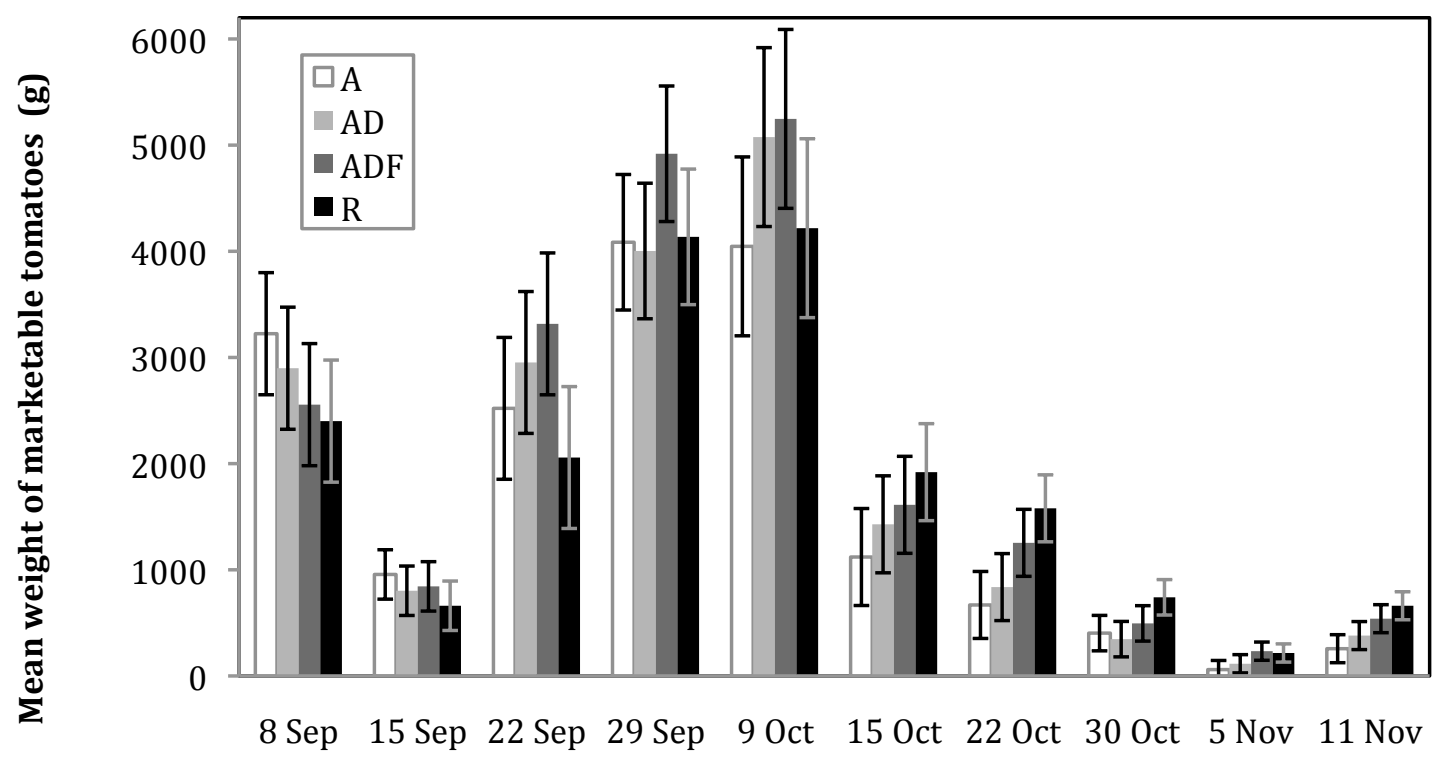

Harvest Date

Figure 4-2. Effects of one Actinovate ${ }^{\circledR}$ application (A), repeated drip Actinovate ${ }^{\circledR}$ applications (AD), repeated drip + foliar Actinovate ${ }^{\circledR}$ applications (ADF), and one Rootshield $^{\circledR}$ application (R) on mean tomato yield in $\mathrm{g}$. Error bars indicate $95 \%$ Confidence Intervals. Means with overlapping error bars are not significantly different.

\section{Number of Marketable Fruits}

The mean number of marketable fruits per plot was significantly greater overall in the ADF treatment than in the A or R treatments at $\alpha=0.05$ (Table 4-3).

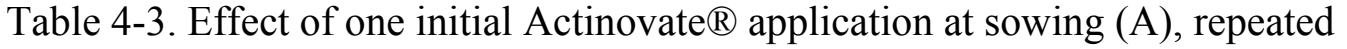
Actinovate ${ }^{\circledR}$ applications through drip tape (AD), repeated drip and foliar Actinovate ${ }^{\circledR}$ applications (ADF), and one initial Rootshield ${ }^{\circledR}$ application $(\mathrm{R})$ on mean number of marketable fruits in each plot for each harvest day.

\begin{tabular}{|c|c|c|c|c|}
\hline \multirow{2}{*}{ Treatment } & \multirow{2}{*}{$\begin{array}{l}\text { Mean Yield } \\
\text { (\# of fruits) }\end{array}$} & \multirow{2}{*}{ Std. Error } & \multicolumn{2}{|c|}{$95 \%$ Confidence Interval } \\
\hline & & & Lower Bound & Upper Bound \\
\hline A & $6.67 \mathrm{bc}$ & 0.328 & 6.02 & 7.32 \\
\hline $\mathrm{AD}$ & $7.41 \mathrm{ab}$ & 0.328 & 6.76 & 8.06 \\
\hline $\mathrm{ADF}$ & $8.31 \mathrm{a}$ & 0.328 & 7.66 & 8.96 \\
\hline $\mathrm{R}$ & $7.23 \mathrm{bc}$ & 0.328 & 6.58 & 7.88 \\
\hline
\end{tabular}

Values followed by different letters within a column differ significantly (LSD adjustment for multiple comparisons, $\mathrm{P}<0.05$ ) 
A treatment effect was detected for mean number of marketable fruits on several harvest days ( $\mathrm{P}=0.01)$, but no clear trend was observed for the differences (Fig. 4-2).

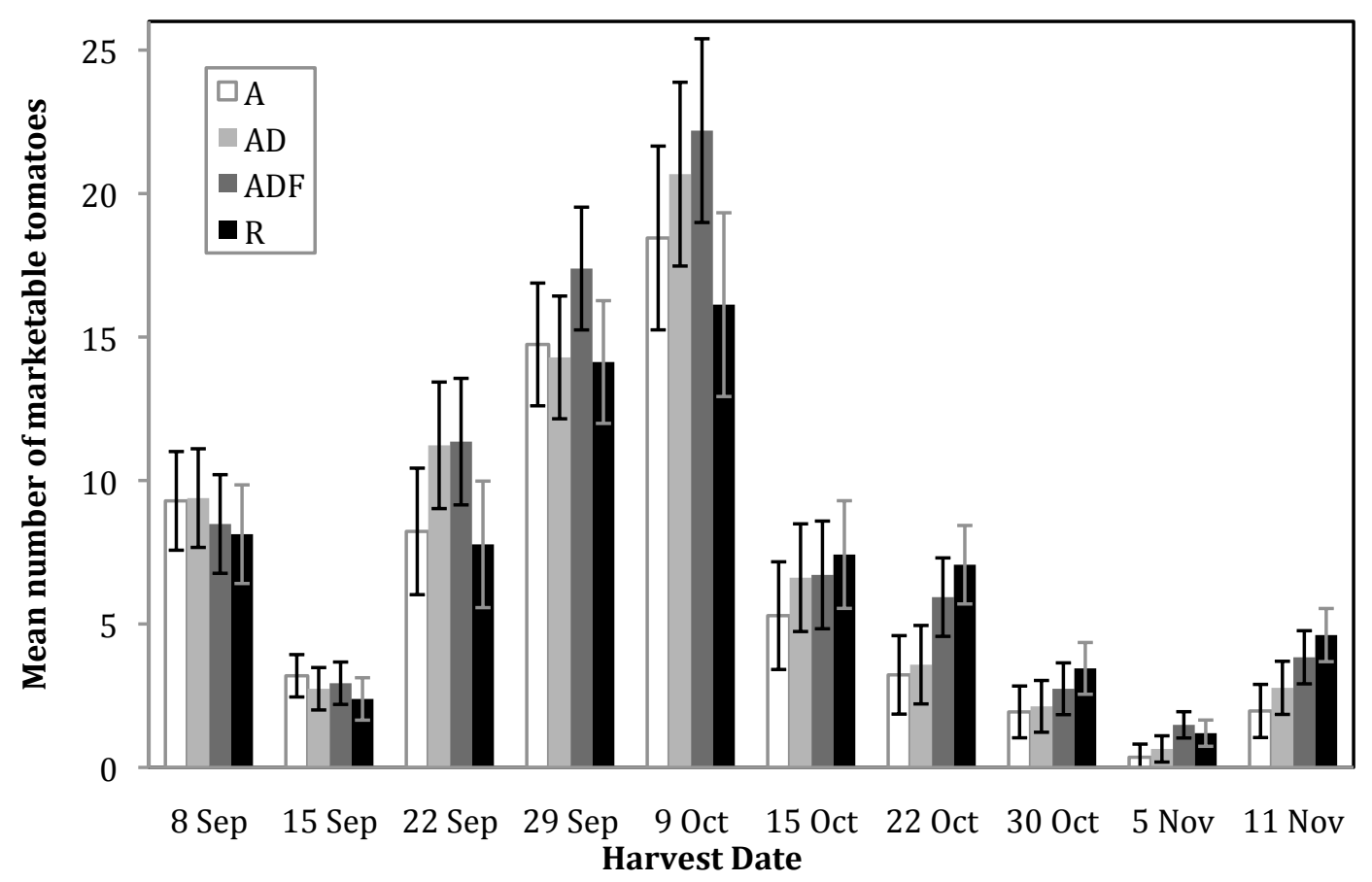

Figure 4-3. Effects of one Actinovate ${ }^{\circledR}$ application (A), repeated drip Actinovate ${ }^{\circledR}$ applications (AD), repeated drip + foliar Actinovate ${ }^{\circledR}$ applications (ADF), and one Rootshield $^{\circledR}$ application (R) on tomato yield, in number of marketable tomatoes. Error bars indicate $95 \%$ Confidence Intervals. Means with overlapping error bars are not significantly different.

\section{Quality}

Tomato yield quality was determined as the percentage of marketable quality fruits out of the total number of fruits harvested from each plot. The number of fruits was used in the calculation rather than the weight because the tomatoes unfit for sale were often too small or were wilted, shriveled, partially eaten, or reduced in weight by rot. The percentage of marketable fruits was significantly lower over the course of the field experiment for the A treatment compared to all other treatments (Table 4-4). 
Table 4-4. Effect of one initial Actinovate $\AA$ application at sowing (A), repeated Actinovate ${ }^{\circledR}$ applications through drip tape (AD), repeated drip and foliar

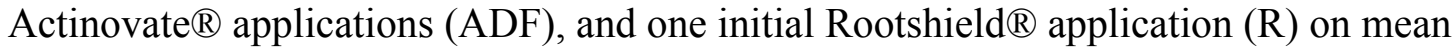
marketable percentage of harvested tomatoes.

\begin{tabular}{crrcc}
\hline \multirow{2}{*}{ Treatment } & $\begin{array}{c}\text { Mean Marketable } \\
\text { \% of Yield }\end{array}$ & \multirow{2}{*}{ Std. Error } & \multicolumn{2}{c}{$95 \%$ Confidence Interval } \\
\cline { 4 - 5 } & $55.25 \mathrm{a}$ & 0.024 & $50.56 \%$ & $59.99 \%$ \\
$\mathrm{~A}$ & $67.10 \mathrm{~b}$ & 0.024 & $62.62 \%$ & $71.44 \%$ \\
$\mathrm{AD}$ & $68.23 \mathrm{~b}$ & 0.024 & $63.78 \%$ & $72.52 \%$ \\
$\mathrm{ADF}$ & $71.62 \mathrm{~b}$ & 0.024 & $67.20 \%$ & $75.76 \%$ \\
$\mathrm{R}$ & &
\end{tabular}

Values followed by different letters within a column differ significantly (LSD adjustment for multiple comparisons, $\mathrm{P}<0.05$ )

No treatment effect was detected for specific harvest dates for the percentage of marketable fruits at $\alpha=0.05$ (Fig. 4-4).

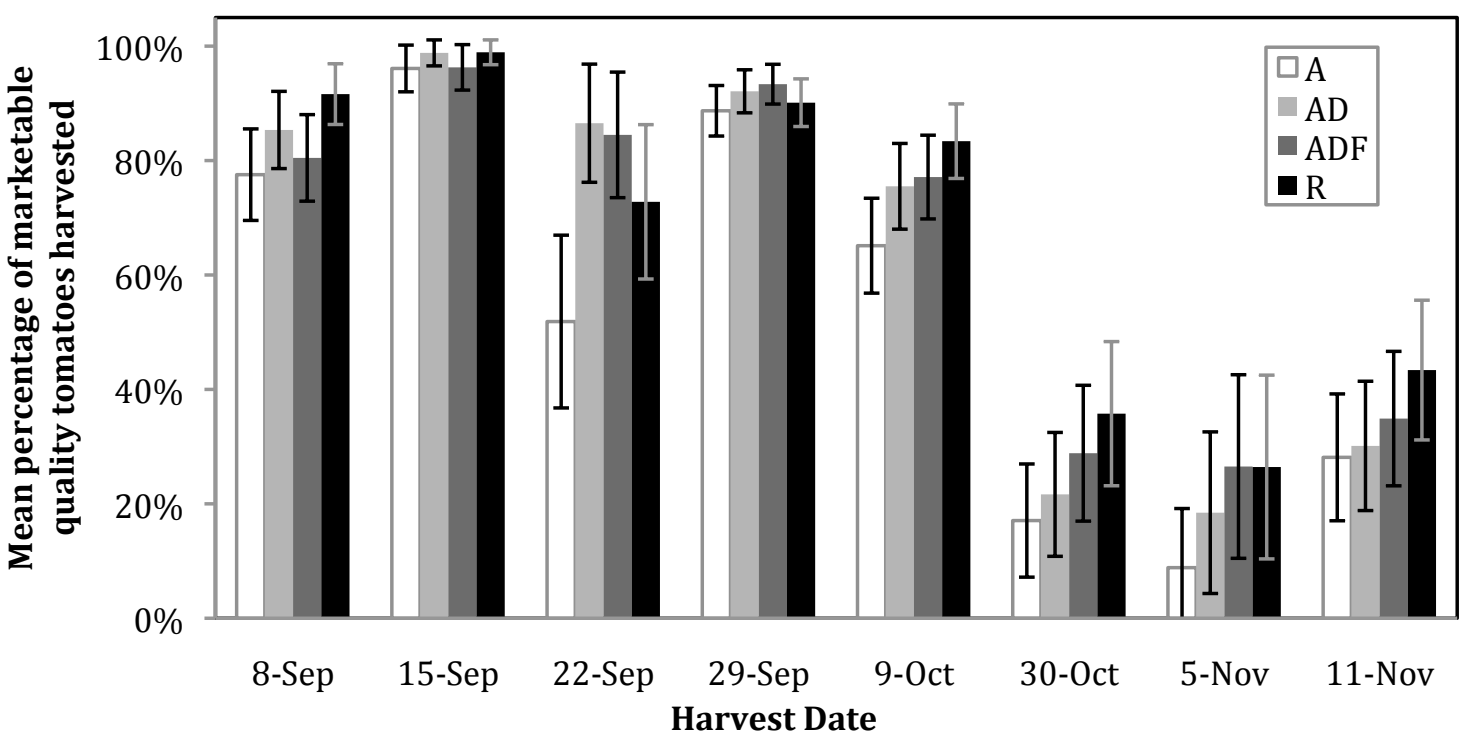

Figure 4-4. Effects of one Actinovate ${ }^{\circledR}$ application (A), repeated drip Actinovate ${ }^{\circledR}$ applications (AD), repeated drip + foliar Actinovate ${ }^{\circledR}$ applications (ADF), and one Rootshield $^{\circledR}$ application (R) on marketable percentage of tomatoes. Error bars indicate 95\% Confidence Intervals. Means with overlapping error bars are not significantly different. Data for 15 and 22 October were not collected by workers due to miscommunications arising from language barriers. 


\section{Disease Presence in Plants}

In spite of early blight infection the previous year, powdery mildew was the only foliar fungal disease to develop over the course of the field experiment. Plants in the ADF treatment had significantly more powdery mildew infection overall over the course of the field experiment than plants in the A treatment (Table 4-5).

Table 4-5. Effect of one initial Actinovate ${ }^{\circledR}$ application at sowing (A), repeated Actinovate ${ }^{\circledR}$ applications through drip tape $(\mathrm{AD})$, repeated drip and foliar Actinovate ${ }^{\circledR}$ applications (ADF), and one initial Rootshield $\AA$ application $(\mathrm{R})$ on percentage of total leaf area with powdery mildew symptoms.

\begin{tabular}{|c|c|c|c|c|}
\hline \multirow{2}{*}{ Treatment } & \multirow{2}{*}{$\begin{array}{c}\text { Mean } \% \text { of leaf } \\
\text { area with symptoms }\end{array}$} & \multirow{2}{*}{ Std. Error } & \multicolumn{2}{|c|}{$95 \%$ Confidence Interval } \\
\hline & & & Lower Bound & Upper Bound \\
\hline A & $2.212 \mathrm{a}$ & 0.064 & 2.090 & 2.342 \\
\hline $\mathrm{AD}$ & $2.377 \mathrm{ab}$ & 0.064 & 2.246 & 2.517 \\
\hline $\mathrm{ADF}$ & $2.416 \mathrm{~b}$ & 0.064 & 2.282 & 2.557 \\
\hline $\mathrm{R}$ & $2.333 \mathrm{ab}$ & 0.064 & 2.201 & 2.472 \\
\hline
\end{tabular}

Values followed by different letters within a column differ significantly (LSD adjustment for multiple comparisons, $\mathrm{P}<0.05$ )

Significant differences in the mean amount of powdery mildew presence as a percentage of total leaf area were detected among the different treatments on several days $(\mathrm{P}=0.01)$, but no clear trends were found (Fig 4-5). 


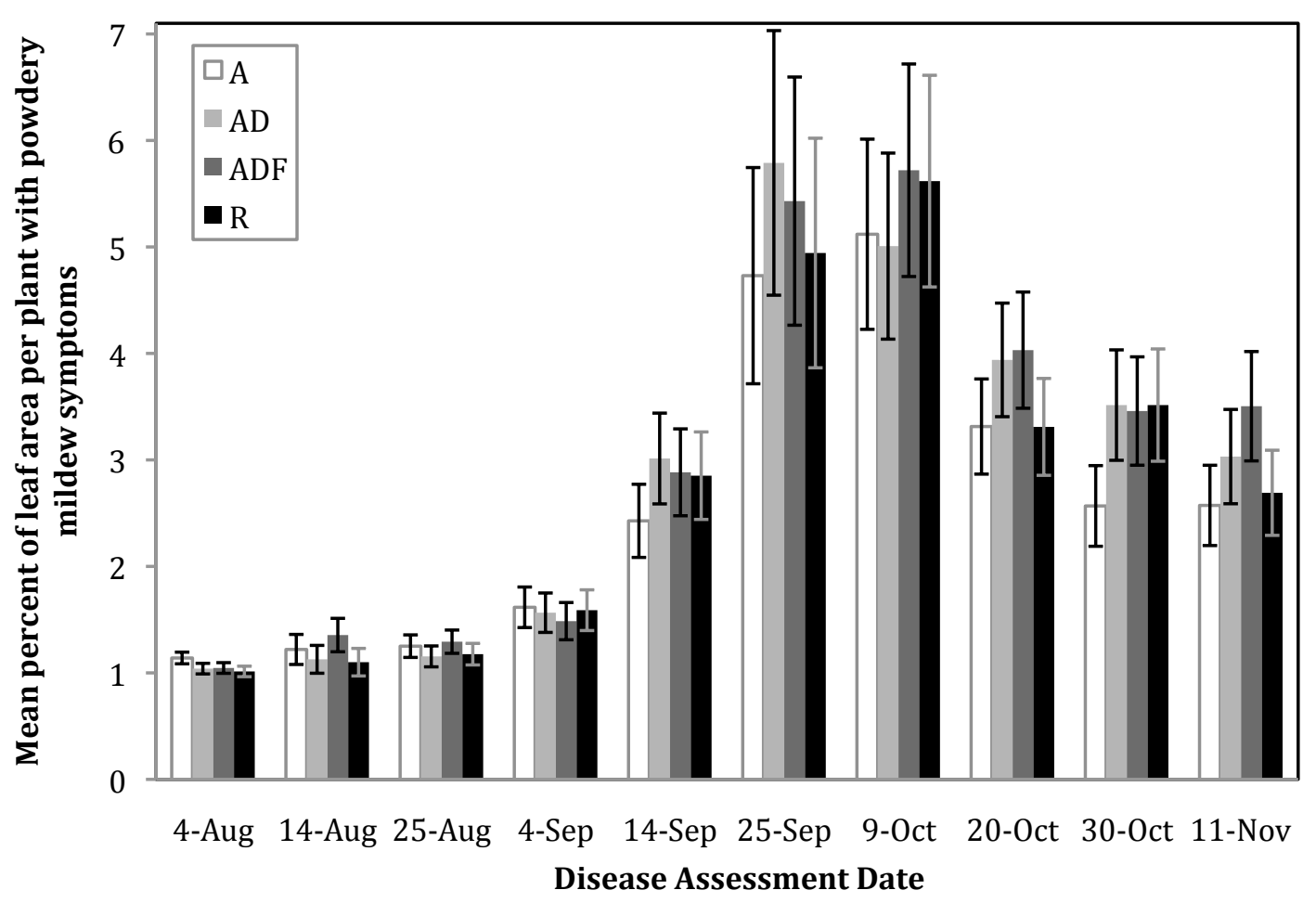

Figure 4-5. Effects of one Actinovate ${ }^{\circledR}$ application (A), repeated drip Actinovate ${ }^{\circledR}$ applications (AD), repeated drip + foliar Actinovate ${ }^{\circledR}$ applications (ADF), and one Rootshield $^{\circledR}$ application (R) on mean percentage of total leaf area with powdery mildew symptoms. Error bars indicate 95\% Confidence Intervals. Means with overlapping error bars are not significantly different.

Verticillium presence did not significantly differ among tomatoes with the different treatments $($ Test statistic $(H)=0.52$, degrees of freedom $(D F)=3, P=0.915, N=9$ for each treatment). Sclerotinia presence did not significantly differ among tomatoes with the different treatments $(\mathrm{H}=1.06, \mathrm{DF}=3, \mathrm{P}=0.787, \mathrm{~N}=9$ for each treatment $)$.

Overall plant vigor did not differ significantly among the different treatments over the course of the field trial (Fig. 4-6). 


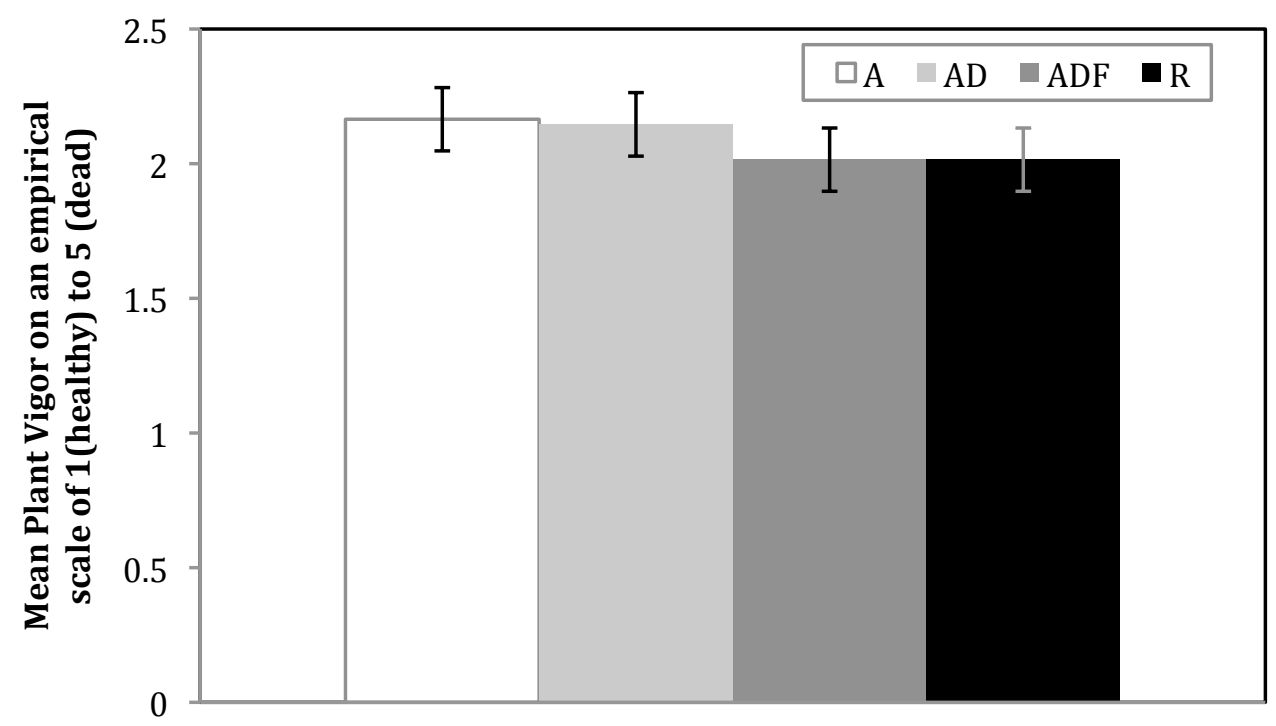

Figure 4-6. Overall plant vigor for tomatoes treated with one Actinovate ${ }^{\circledR}$ application (A), repeated drip Actinovate ${ }^{\circledR}$ applications (AD), repeated drip + foliar Actinovate ${ }^{\circledR}$ applications (ADF), and one Rootshield ${ }^{\circledR}$ application (R). Error bars indicate $95 \%$ Confidence Intervals. Means with overlapping error bars are not significantly different. 


\section{CHAPTER 5}

Discussion

\section{Greenhouse}

Results in the greenhouse experiment may have been influenced by the foliar application of other products to control fungal pathogens following the initial Actinovate $^{\circledR}$ or Rootshield ${ }^{\circledR}$ seed drenches. The products had to be applied due to Greenheart nursery regulations, in order to minimize the occurrence of plant pathogens in their commercial organic greenhouse. In a commercial greenhouse, it is unrealistic to use only one product to control fungal pathogens between sowing seeds and the date they are ready for transport.

\section{Germination and Survival}

No significant differences were found in tomato seedling germination and survival rates between seeds treated with Actinovate ${ }^{\circledR}$ or Rootshield $^{\circledR}$. Trichoderma harzianum has been shown to stimulate the initial germination of tomato seeds in the past, but was not shown to affect the final number of germinated seeds (Celar and Valic, 2005). Streptomyces lydicus WYEC 108 has been shown to improve plant growth of some plants in the absence of plant pathogens (Salove, 2002, Tokala et al., 2002).

\section{Plant Height}

No significant difference was found between plant heights of plants treated with Actinovate $^{\circledR}$ or Rootshield $^{\circledR}$ seed drenches. Since the plant heights were measured eleven weeks after sowing, the germination date of seeds would not have a great impact on plant height, since seeds germinating even 3 days earlier would only represent $4 \%$ of the growing period. These results may agree with results found in the past, when Rootshield ${ }^{\circledR}$ 
was not found to significantly increase the plant height of tomato plants compared to untreated plants in the absence of plant pathogens (Srinivasan et al., 2009).

\section{Root and Shoot Weights}

No significant difference was found between plant root and shoot weights of plants treated with Actinovate ${ }^{\circledR}$ or Rootshield ${ }^{\circledR}$ seed drenches. Radish and carrot seedlings treated with S. lydicus WYEC 108 had higher average weights than untreated seeds in another study (Salove, 2002). Rootshield ${ }^{\circledR}$ was not found to significantly increase the plant biomass of tomato plants compared to untreated plants (Srinivasan et al., 2009).

Field

\section{Plant Height}

The four treatments used in this study included one Actinovate ${ }^{\circledR}$ soil drench at sowing (A), repeated drip Actinovate ${ }^{\circledR}$ applications (AD), repeated drip and foliar Actinovate $^{\circledR}$ applications (ADF), and one Rootshield ${ }^{\circledR}$ soil drench at sowing (R). No significant differences in plant height were found among plants with the different treatments. A major hurdle to using plant-growth promoting bacteria is proving that bacteria that have been used effectively in the laboratory can be used successfully in the field (Salove, 2002).

Uncontrolled variables may have contributed to these results, including pests, weather, transplanting errors, and other environmental conditions. Plants throughout the field were damaged by gophers, which partially or completely destroyed plant root systems and above-ground plant parts. Out of 93 plants per treatment, 5 plants in A (5.4\%), 6 plants in $\mathrm{AD}(6.5 \%), 14$ plants in $\mathrm{ADF}(15.1 \%)$, and 9 plants in $\mathrm{R}(9.7 \%)$ were 
known to be killed or severely damaged by gophers. The root systems of many other plants were probably compromised by gophers as well. Weather remained between $4.4^{\circ}$ $29.4^{\circ} \mathrm{C}$, the optimum temperature listed on the Actinovate ${ }^{\circledR}$ label, from the transplant date to the last date heights were measured, except for one day (Appendix B). On 4 June, the temperature reached $30^{\circ} \mathrm{C}$, on a day when actinovate $^{\circledR}$ was applied through the drip system. Although the Actinovate ${ }^{\circledR}$ was applied in the morning before the temperature rose to its peak, the high temperature may have reduced the effectiveness of the Actinovate $^{\circledR}$ applied on that day. After inspecting the transplants in one of the rows in the ADF treatment one week after planting, the grower believed that the plants had not been planted deep enough in the ground. This could have been the main reason plants in that row had poorer growth than other rows. The ability of the Streptomycetes to increase tomato plant growth may have also been decreased by the existing soil microflora. In this case, applying Actinovate ${ }^{\circledR}$ as a seed drench, through the drip irrigation system, or through the irrigation in combination with foliar applications did not increase tomato plant height compared to applying Rootshield ${ }^{\circledR}$ as a seed drench.

\section{Yield}

Many variables not accounted for in the experimental design may have impacted the yield results. Marketable yield was greatly decreased by gophers and rabbits, through plant damage as described above, and through the direct consumption of tomatoes by the animals. Several rows fell over during the experiment due to the excessive weight of the tomato plants bearing fruit. The plants were not uprooted, and the stems did not break, but the plants sometimes remained on the ground for long durations before they were uprighted. In the A treatment, 9 experimental plots fell over and remained on the ground 
for one week in September, and 3 others fell over and were on the ground for three weeks in October. In the AD treatment, 2 plots were on the ground for around three weeks Sep Oct. In the R treatment, 2 plots were on the ground for a week in October. The greater number of plots that fell over earlier in the season and remained on the ground longer in the A treatment may have reduced plant vigor, marketable yields, and fruit quality for that treatment. Marketable yield was also decreased greatly by fruit deformation and corky stylar scars, which are often caused by low temperatures during blossoming and fruit formation (Blancard, 1994). Equipment failures and weather, including broken pumps, excessive heat, and excessive wind, delayed several Actinovate ${ }^{\circledR}$ applications and plant irrigations (Appendix D). Inclement weather, including rain and heat, and worker availability sometimes delayed harvest, allowing some fruit to go bad.

An unidentified plant disease affected many plants throughout the course of the field experiment. The symptoms included reduced size leaflets, thickening and curling of leaves, deformation of flowers, and purple or blue-tinged discoloration of the leaves. The disease symptoms closely matched those of the disease stolbur, caused by a mycoplasma from the "aster yellows" group, vectored by insects (Blancard, 1994), but the resources to confirm the causal agent of the disease were not available. The average number of plots with the disease symptoms for each treatment for the harvest days were calculated. For A, $3.0 \%$ of the plots had the symptoms. In $\mathrm{AD}, 7.6 \%$, in $\mathrm{ADF}, 1.6 \%$, and in $\mathrm{R}, 3.1 \%$ of the plots showed symptoms of the disease.

\section{Marketable Fruit Weight}

The mean weights of marketable fruit per plot were significantly greater in the ADF treatment than in the A treatment (2102 and 1734g, respectively), and the mean 
weights of marketable fruit per plot were greater in the ADF treatment than in the R treatment $(1859 \mathrm{~g})$, although the means were not significantly different.

The increased yield in the ADF treatment compared to the R treatment could be due to the plant-growth promoting properties of S. lydicus WYEC 108 (Salove, 2002). Increased yield is probably not due to the suppression of fungal pathogens, since foliar applications of Actinovate ${ }^{\circledR}$ were not found to reduce the presence of any foliar fungal plant pathogens. Increased yield could be due to the suppression of Verticillium wilt disease symptoms, even though no differences in Verticillium wilt were found among the different treatments in this experiment, possibly due in part to the small number of samples gathered and the small percentage of samples with the causal agent $V$. dahliae present. The difference could also be due to the possible benefits of spraying tomatoes with water once a week, or the many uncontrollable factors in this experiment.

The differences in yield between the ADF, A, and R treatments for 11 weekly harvests in a season, as in this experiment, would translate into approximately $\$ 308,000$ per hectare for tomatoes in the ADF treatment, $\$ 254,000$ per hectare for tomatoes in the A treatment, and $\$ 273,000$ per hectare for the tomatoes in the R treatment (Appendix C). (For an acre of tomatoes, the revenue for the season based on the different yields would be $\$ 125,000, \$ 103,000$, and $\$ 110,000$, respectively.) The increased revenue would be enough to offset the costs of purchasing and applying Actinovate ${ }^{\circledR}$ over the course of the season. The Actinovate ${ }^{\circledR}$ for the soil drench and foliar application rates used in this experiment costs approximately $\$ 6,700$ per hectare $(\$ 2,700$ per acre), over six months, in addition to varying application costs. 


\section{Number of Marketable Fruits}

The mean number of marketable fruits per plot was significantly greater overall in the ADF treatment than in the A or R treatments (8.31, 6.67, and 7.23, respectively). These results are very similar to the results for the weight of marketable fruits, indicating that the number of marketable tomatoes harvested and their total weight are closely correlated, and are most likely influenced by the same factors.

\section{Quality}

The percentage of marketable fruits was significantly lower over the course of the field experiment for the A treatment compared to all other treatments. No existing research offers explanations for this occurrence. The greater incidence of experimental plots falling over in the A treatment probably decreased the ratio of marketable to cull fruits for that treatment. Another source of error was that many damaged tomatoes fell to the ground between harvests, where they rotted or were smashed into the soil, and were often impossible to count. This could help explain the unexpected results.

\section{Disease Presence in Plants}

The greater amount of powdery mildew presence in the ADF treatment compared to the A treatment could have been due to the foliar application of water with the Actinovate $^{\circledR}$, which may have briefly increased the relative humidity on the leaf surfaces each week. Increased water availability in the air increases spore germination in favorable temperatures. At $25^{\circ} \mathrm{C}$, spore germination of L. taurica increases with increasing relative humidity (Guzman-Plazola et al., 2003). Previous studies have shown foliar applications of various biocontrols, including Actinovate ${ }^{\circledR}$, to be effective at 
reducing powdery mildew development (Silva et al., 2004; Koné et al., 2010; Segarra et al., 2009; McGrath, 2009; Bardin et al., 2008), but those experiments included spraying the plants with water as the control treatment. Those studies did not include a treatment where the plants were not sprayed with any water, as in this experiment, so it is unknown whether the plants in the ADF treatment in this experiment were affected by the foliar application of water. Although the mean percentage of leaf area with powdery mildew symptoms was statistically significantly higher in the ADF treatment than in the $\mathrm{A}$ treatment $(2.416 \%$ and $2.212 \%$, respectively), the difference of $0.204 \%$ of the total plant leaf area with powdery mildew symptoms is a negligible difference in commercial tomato production.

Several sources of error could have influenced the results. The unknown disease described above interfered with powdery mildew data collection. On days when disease was assessed, an average of $2.0 \%$ of the observed A plants had symptoms, $6.1 \%$ of the AD plants, $1.1 \%$ of the ADF plants, and $1.8 \%$ of the R plants surveyed for plant disease had the symptoms of the unknown disease. The presence of discolored and deformed leaves made it difficult or impossible to determine the amount of powdery mildew presence in the plants.

Other sources of experimental error included delayed Actinovate ${ }^{\circledR}$ applications and varietal impurity. Drip or foliar Actinovate ${ }^{\circledR}$ treatment was delayed on five occasions from $1-4$ days due to broken equipment, rain, or hot weather. Both foliar and drip applications were made two weekends in a row by mistake once (Appendix D). One of the experimental plots contained a Roma variety tomato plant, so the data from that plant were not used. However, the plant had much more powdery mildew than most of the 
others, so it could have served as a disease reservoir for the nearby plants in the ADF treatment. These occurrences could have impacted the powdery mildew presence on the plant foliage.

No significant differences were found among the four treatments for the number of plants with Verticillium or Sclerotinia present. Previous studies found that the biocontrols Plantshield ${ }^{\circledR}$, based on T. harzianum, and SoilGard ${ }^{\circledR}$, based on Gliocladium virens could reduce the presence of Sclerotinia in tomatoes (Abdullah et al., 2008), but Actinovate ${ }^{\circledR}$ was not found to reduce the presence of Sclerotinia here. The biocontrol species Streptomyces pulcher and S. canescens were found to significantly inhibit fungal growth of Verticillium albo-atrum in tomato (Elabyad et al., 1993). Pseudomonas sp. strain PsJN was found to significantly reduce Verticillium wilt progress when added to two-week old tomato seedlings in vitro (Sharma and Nowak, 1998). In this experiment, Actinovate ${ }^{\circledR}$ was not found to reduce the presence of Verticillium.

Some difficulties with data collection made determining the presence of the soil borne fungal diseases Verticillium and Sclerotinia difficult. The vast majority of the plants showed signs of wilting or severe wilting throughout the course of the field experiment, in addition to dropping leaves, especially from late August - early November, when several days had high temperatures over $30^{\circ} \mathrm{C}$. The wilting could have been due to heat, water stress, vascular wilt diseases, or a combination of these causes. This made it difficult to single out specific plants with diseases due to soil borne fungal pathogens. The plant vigor measurements often reflected the amount of wilted or dropped leaves for plants among the different treatments, and there were no significant differences among plant vigor for the plants in the four treatments. On the day plant stems and roots 
were collected, only limited samples could be obtained due to the removal of the tomato stakes and inclement weather.

\section{Summary}

In the greenhouse experiment, no significant differences were found in tomato seedling germination and survival rates between seeds treated with Actinovate ${ }^{\circledR}$ or Rootshield $^{\circledR}$. No significant differences were found between plant heights or plant root and shoot weights of plants treated with Actinovate ${ }^{\circledR}$ or Rootshield ${ }^{\circledR}$ seed drenches. These plant parameters may have been enhanced by both biocontrol products, or not affected by either.

In the field trial, no significant differences in plant height were found among plants with the four different treatments: one Actinovate ${ }^{\circledR}$ soil drench at sowing (A), repeated drip Actinovate ${ }^{\circledR}$ applications (AD), repeated drip and foliar Actinovate ${ }^{\circledR}$ applications (ADF), and one Rootshield ${ }^{\circledR}$ soil drench at sowing (R). Predation by gophers and rabbits, weather, an unidentified plant disease, and transplanting errors may have influenced these results.

Marketable fruit weight was greater in the ADF treatment than in the A treatment, possibly due to the plant-growth promoting properties of S. lydicus WYEC 108 or due to the suppression of Verticillium wilt disease symptoms, if the ADF treatment suppressed the disease without being detected. The difference could also be due to the uncontrollable factors in this experiment, such as gophers, rabbits, fallen rows, inclement weather, and an unidentified plant disease. The number of marketable fruits was significantly greater in the ADF treatment than in the A or R treatments, which were closely correlated to the marketable yield weights, and were probably influenced by the same factors. The 
percentage of marketable fruits was significantly lower over the course of the field experiment for the A treatment compared to all other treatments, which contradicted expectations, and was probably greatly influenced by sources of error previously listed.

The increased amount of powdery mildew in the ADF treatment compared to the A treatment could have been in response to the foliar application of water, which may have increased spore germination of L. taurica. While statistically significantly different, the difference in powdery mildew presence among treatments was negligible for commercial tomato production. Sources of experimental error for disease observations included the unidentified plant disease, delayed Actinovate ${ }^{\circledR}$ applications, and varietal impurity.

No significant differences were found among the four treatments for the number of plants with Verticillium or Sclerotinia present. Gathering the data for these observations was difficult because most plants in the field showed symptoms of vascular wilt, and only a limited number of samples could be collected.

In the greenhouse, no significant differences were found in tomato seedling germination and survival, height, or shoot and root weight among plants treated with Actinovate $^{\circledR}$ or Rootshield ${ }^{\circledR}$ seed drenches at the time of sowing. In the field trial, the most notable result was the greater marketable yield in the ADF treatment than in the A treatment, although it is not understood why this occurred.

It is difficult to draw conclusions from the results of only one growing season. In the future, the effects of Actinovate ${ }^{\circledR}$ on Verticillium wilt on tomato can be further investigated, especially where the disease is a major problem requiring the application of 
fungicides. The effects of Actinovate ${ }^{\circledR}$ on other fungal pathogens of tomato could also be studied where their occurrence is detrimental to the crop. 


\section{LIST OF REFERENCES}

Abdullah, M.T., N.Y. Ali, and P. Suleman. 2008. Biological control of Sclerotinia sclerotiorum (Lib.) de Bary with Trichoderma harzianum and Bacillus amyloliquefaciens. Crop Prot. 27:1354-1359.

Almeida, F.B., F.M. Cerqueira, R.N. Silva, C.J Ulhoa, and A.L. Lima. 2007. Mycoparasitism studies of Trichoderma harzianum strains against Rhizoctonia solani: Evaluation of coiling and hydrolytic enzyme production. Biotechnol. Lett. 29:1189-1193.

Bardin, M., J. Fargues and P.C. Nicot. 2008. Compatibility between biopesticides used to control grey mould, powdery mildew and whitefly on tomato. Biol. Control 46:476-483.

Beyer, M., and H. Diekmann. 1985. The chitinase system of Streptomyces sp. ATCC 11238 and its significance for fungal cell wall degradation. Appl. Microbiol. Biotechnol. 23:140-146.

Blancard, D. 1994. A colour atlas of tomato diseases: Observation, identification and control. Manson Publishing, London, UK.

Boriss, H., and Brunke, H. 2009. Fresh tomatoes profile. Available at http://www.agmrc. org/commodities_products/vegetables/fresh_tomatoes_profile.cfm (verified 26 Feb. 2010). Ag Marketing Resource Center, Washington, DC.

Celar, F., and N. Valic. 2005. Effects of Trichoderma spp. and Gliocladium roseum culture filtrates on seed germination of vegetables and maize. Z. Pflanzenkrankh. Pflanzenschutz.- J. Plant Dis. Prot. 112:343-350.

Cuevas, V.C., A.M. Sinohin, and J.I. Orajay. 2005. Performance of selected Philippine species of Trichoderma as biocontrol agents of damping off pathogens and as growth enhancer of vegetables in farmers' field. Philippine Agric. Sci. 88:63-71.

De Curtis, F., G. Lima, D. Vitullo, and V. De Cicco. 2010. Biocontrol of Rhizoctonia solani and Sclerotium rolfsii on tomato by delivering antagonistic bacteria through a drip irrigation system. Crop Prot. 29:663-670.

Elabyad, M.S., M.A. Elsayed, A.R. Elshanshoury, and S.M. Elsabbagh. 1993. Towards the biological-control of fungal and bacterial diseases of tomato using antagonistic streptomyces spp. Plant Soil 149:185-195.

Elliott, M., S.F. Shamoun, G. Sumampong, D. James, S. Masri, and A. Varga. 2009. Evaluation of several commercial biocontrol products on European and North American populations of Phytophthora ramorum. Biocontrol Sci. Technol. 99:1007-1021. 
Elmer, W.H., and R.J. McGovern. 2004. Efficacy of integrating biologicals with fungicides for the suppression of Fusarium wilt of cyclamen. Crop Prot. 23:909914.

Guzman-Plazola, R.A., R.M. Davis, and J.J. Marois. 2003. Effects of relative humidity and high temperature on spore germination and development of tomato powdery mildew (Leveillula taurica). Crop Port. 22:1157-1168.

Hasna, M.K., E. Ogren, P. Persson, A. Martensson, and B. Ramert. 2009. Management of corky root disease of tomato in participation with organic tomato growers. Crop Prot. 28:155-161.

Inbar, J., and I. Chet.1991. Evidence that chitinase produced by Aeromonas caviae is involved in the biological control of soil-borne plant pathogens by this bacterium. Soil Biol. Biochem. 23:973-978.

Jones, J.B., J.P. Jones, R.E. Stall, and T.A. Zitter (ed.) 1991. Compendium of Tomato Diseases. 1st ed. APS Press, St. Paul, MN.

Koné, S.B., A. Dionne, R.J. Tweddell, H. Antoun, and T.J. Avis. 2010. Suppressive effect of non-aerated compost teas on foliar fungal pathogens of tomato. Biological Control 52:167-173.

Leisso, R. S., P.R. Miller, and M.E. Burrows. 2009. Influence of biological and fungicidal seed treatments on chickpea (Cicer arietinum) damping off. Can. J. Plant Pathol. 31:38-46.

Mahadevan, B., and D.L. Crawford. 1997. Properties of the chitinase of the antifungal biocontrol agent Streptomyces lydicus WYEC108. Enzy. Microb. Technol. 20:489-493.

Matheron, M.E., and M. Porchas. 2008. Effectiveness of the biopesticides Actinovate and Kaligreen within a management program for powdery mildew on cantaloupe. In Centennial Meeting Proceedings [CD-ROM]. APS, Minneapolis, MN.

McGrath, M.T. 2009. Evaluation of treatments for managing foliar diseases in organically-produced tomato. Acta Hortic. 808:137-141.

Minitab. 2010. MINITAB 16. Minitab Inc., State College, PA.

Minuto A., Q. Migheli, and A. Garibaldi. 1995. Evaluation of antagonistic strains of Fusarium spp. in the biological and integrated control of Fusarium wilt of cyclamen. Crop Prot. 14:221-226.

Panthee, D.R., and F. Chen. 2010. Genomics of fungal disease resistance in tomato. Curr. Genomics 11:30-39. 
Reed, J.P., F.R. Hall, and R.M. Riedel. 1993. Biological implications of drift from sprayers in tomato fungicide field trials. Plant Dis. 77:186-189.

Salove, M.H. 2002. Plant growth promotion and siderophore production by selected rootcolonizing, nonpathogenic Streptomyces species. M.S. thesis. Univ. of Idaho, Moscow.

Segarra, G., M. Reis, E. Casanova, and M.I. Trillas. 2009. Control of powdery mildew (Erysiphe polygoni) in tomato by foliar applications of compost tea. J. Plant Pathol. 91:683-689.

Sharma, V.K., and J. Nowak. 1998. Enhancement of verticillium wilt resistance in tomato transplants by in vitro co-culture of seedlings with a plant growth promoting rhizobacterium (Pseudomonas sp. strain PsJN). Can. J. Microbiol. 44:528-536.

Silva, H.S.A., R.D. Romeiro, D. Macagnan, B.D. Halfeld-Vieira, M.C.B. Pereira, and A. Mounteer. 2004. Rhizobacterial induction of systemic resistance in tomato plants: non-specific protection and increase in enzyme activities. Biological Control 29:288-295.

SPSS Statistics. 2003. SPSS Statistics 11.0. SPSS Inc., Chicago, IL.

Srinivasan, K., G. Gilardi, A. Garibaldi, and M.L. Gullino. 2009. Bacterial antagonists from used rockwool soilless substrates suppress Fusarium wilt of tomato. J. Plant Pathol. 91:147-154.

Tokala, R.K., J.L. Strap, C.M. Jung, D.L. Crawford, M.H. Salove, L.A. Deobald, J.F. Bailey, and M.J. Morra. 2002. Novel plant-microbe rhizosphere interaction involving Streptomyces lydicus WYEC108 and the pea plant (Pisum sativum). Appl. Environ. Microbiol. 68:2161-2171.

University of California. 1990. Integrated Pest Management for Tomatoes. 3rd ed. Publication 3274. Division of Agriculture and Natural Resources, University of California, Oakland, CA.

Yuan, W. M., and D. L. Crawford. 1995. Characterization of Streptomyces lydicus WYEC108 as a potential biocontrol agent against fungal root and seed rots. Appl. Environ. Microbiol. 61:3119-3128. 


\section{APPENDIX A}

Individual tomato plants, with dead and missing plants identified. Plots of three plants were designated in the field and flagged with pink ribbon on 22 May 2010.

\begin{tabular}{|c|c|c|c|c|c|c|c|c|c|c|c|c|c|c|c|c|c|c|}
\hline Row & 3 & 4 & 5 & 6 & 7 & 8 & 9 & 10 & 11 & 12 & 13 & 14 & 15 & 16 & 17 & 18 & 19 & 20 \\
\hline & & & & & & & & & & & & & & & & & & \\
\hline & & & & & & & & & & & & & & & & & & \\
\hline & & & & & & & & & & & & & & & & & & \\
\hline & & & & & & & & & & & & & & 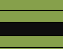 & & & & \\
\hline & & & & & & & & & & & & & $\bar{z}$ & & & & & \\
\hline & & & & & & & & & & & 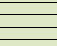 & & $\overline{\bar{Z}}$ & & & & & \\
\hline & & & & & 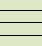 & & & & & & 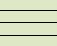 & & 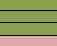 & & & & & \\
\hline & & & & & 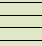 & & & & & & $\overline{\bar{Z}}$ & & $\overline{\bar{Z}}$ & & & & & \\
\hline & & & & & & & & & & & $\bar{Z}$ & & & & & & & \\
\hline & & & & & & & & & & & 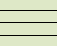 & 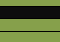 & 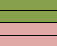 & $\bar{z}$ & & & & \\
\hline & & & & & & & & & & & $\overline{\bar{Z}}$ & & & 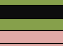 & & & & \\
\hline & & & & & & & & & $\overline{\bar{Z}}$ & & 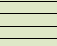 & 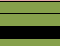 & 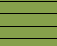 & & & & & \\
\hline & & & & & & & & & & & 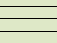 & & $\bar{\nu}$ & & & & & \\
\hline & & & & & $\bar{Z}$ & & & & & & $\overline{\bar{Z}}$ & & 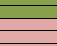 & & & & & \\
\hline & & & & & & & & & & & & & 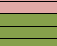 & & & & & \\
\hline & & & & & & & & & & & & & & & & & & \\
\hline & & & & & & & & & & & & & 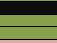 & & & & & \\
\hline & & & & & & & & & & & $\bar{Z}$ & & $\overline{\bar{Z}}$ & & $\overline{\bar{z}}$ & & & \\
\hline & & & & & & & & & & & $\bar{Z}$ & & & & & & & \\
\hline & & & & & & & & & & & $\bar{Z}$ & & $\overline{\bar{\nu}}$ & & & $E$ & & \\
\hline & & & & & & & & & & & & & $\overline{\bar{Z}}$ & & & & & \\
\hline & & & & & & & & & & & $\bar{Z}$ & & & & & & & \\
\hline & & & & & & & & & & & $\bar{z}$ & & $\overline{\bar{\nu}}$ & & & & & \\
\hline & & & & & & & & & & & $\bar{z}$ & & & & & & & \\
\hline & & & & & & & & & & & & & $\bar{z}$ & & & 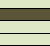 & & \\
\hline & & & & & & & & & & & $\overline{\bar{z}}$ & & $\overline{\bar{Z}}$ & & 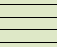 & & & \\
\hline & & & & & & & & & & & $\overline{\bar{Z}}$ & & $\bar{Z}$ & & $\bar{E}$ & & & \\
\hline & & & & & & & & & & & & & 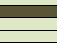 & & & & & \\
\hline & & & & & & & & & & & $\bar{Z}$ & & & & & & & \\
\hline & 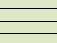 & $=$ & $\bar{E}$ & & - & E & $\overline{-}$ & & & & $\overline{\bar{Z}}$ & $\bar{E}$ & $\bar{z}$ & 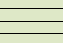 & $\bar{E}$ & & & \\
\hline & 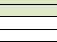 & & & & & & & & & & $\bar{E}$ & & $\bar{z}$ & & & & & \\
\hline & & & & & & & & & & & $\bar{Z}$ & & & $\bar{z}$ & & & & \\
\hline & & & & & & & & & & & & & & 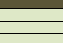 & $\overline{\bar{E}}$ & & & \\
\hline & 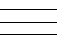 & & & & & & & & & & $\bar{~}$ & $\overline{\bar{z}}$ & $\bar{z}$ & $\bar{z}$ & $\overline{\bar{z}}$ & & & \\
\hline & & & & & 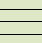 & & 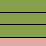 & & & & 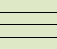 & & $\bar{Z}$ & & & & & \\
\hline & & & & & & & & & & & & 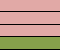 & & & & & & \\
\hline
\end{tabular}

Legend

Plant in sampling area

Missing plant

$\square$ Plant in an unsampled area

Dead plant

Plant in a sampling plot 


\section{APPENDIX B}

Weather in Los Alamos from April 2011 - November 2011

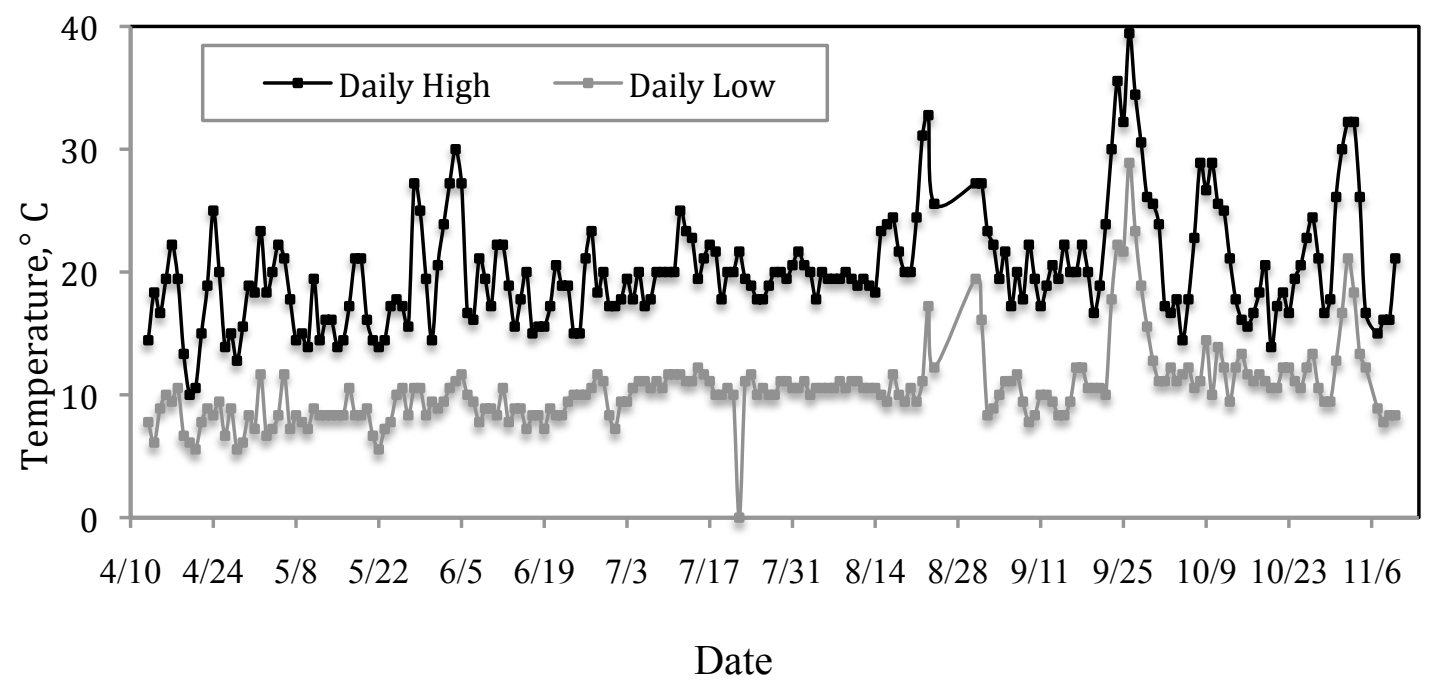

Data came from Weather Underground < wunderground.com>, MesoWest

LOMPOC HS \& P CA US SBCAPCD weather station in Los Alamos (MOXLOM). 


\section{APPENDIX C}

Projected revenue for tomato yields for three different treatments based on the calculated mean plot yields in this field trial. Projections are for each of three treatments if they had been planted over an entire hectare or acre at the spacing used in this experiment, with 11 harvests.

For one hectare: 20,000 plants $=6667$ plots $/$ hectare

\begin{tabular}{cccccc}
\hline Treatment & $\begin{array}{c}\text { Mean Plot } \\
\text { Yield }(\mathrm{g})\end{array}$ & $\begin{array}{c}\text { Total yield for } \\
\text { field }(\mathrm{kg})\end{array}$ & $\begin{array}{c}\text { Total boxes } \\
\text { per harvest }\end{array}$ & $\begin{array}{c}\text { Revenue/ } \\
\text { harvest }\end{array}$ & $\begin{array}{c}\text { Revenue for } \\
\text { entire season }\end{array}$ \\
\hline ADF & 2102 & 14014 & 1401 & $\$ 28,028$ & $\$ 308,308.75$ \\
A & 1734 & 11561 & 1156 & $\$ 23,121$ & $\$ 254,332.72$ \\
R & 1859 & 12394 & 1239 & $\$ 24,788$ & $\$ 272,666.97$ \\
\hline
\end{tabular}

For one acre: 8094 plants, with 3 plants per plot $=2698$ plots/acre

\begin{tabular}{cccccc}
\hline Treatment & $\begin{array}{c}\text { Mean Plot } \\
\text { Yield }(\mathrm{g})\end{array}$ & $\begin{array}{c}\text { Total yield for } \\
\text { field }(\mathrm{kg})\end{array}$ & $\begin{array}{c}\text { Total boxes } \\
\text { per harvest }\end{array}$ & $\begin{array}{c}\text { Revenue/ } \\
\text { harvest }\end{array}$ & $\begin{array}{c}\text { Revenue for } \\
\text { entire season }\end{array}$ \\
\hline ADF & 2102 & 5671 & 567 & $\$ 11,342$ & $\$ 124,766.31$ \\
A & 1734 & 4678 & 468 & $\$ 9,357$ & $\$ 102,923.30$ \\
R & 1859 & 5016 & 502 & $\$ 10,031$ & $\$ 110,342.80$
\end{tabular}

Assumptions:

- Each box of tomatoes weights $10 \mathrm{~kg}$

- The wholesale price of each box is $\$ 20$ 


\section{APPENDIX D}

Dates of Actinovate ${ }^{\circledR}$ applications in the field trial.

\begin{tabular}{|c|c|c|c|}
\hline Day & Date & Actinovate Application type and rate & Notes \\
\hline Sat & $17 \mathrm{Apr}$ & First drip application: $12 \mathrm{oz} /$ acre & \\
\hline Sat & 1 May & Foliar: 6oz/acre, Drip: 6oz/acre & \\
\hline Sat & 8 May & Foliar: 6oz/acre & \\
\hline Sat & 15 May & Foliar: 6oz/acre, Drip: 6oz/acre & \\
\hline Sat & 22 May & Foliar: 6oz/acre, Drip: 6oz/acre & \\
\hline Sat & 29 May & Foliar: 6oz/acre & \\
\hline Sat & 5 Jun & Foliar: 6oz/acre, Drip: 6oz/acre & \\
\hline Sat & 12 Jun & Foliar: 6oz/acre & \\
\hline Sat & 19 Jun & Foliar: 6oz/acre, Drip: 6oz/acre & \\
\hline Sat & 26 Jun & Foliar: 6oz/acre & \\
\hline Sat & $3 \mathrm{Jul}$ & Foliar: 6oz/acre, Drip: 6oz/acre & \\
\hline Sat & $10 \mathrm{Jul}$ & Foliar: 6oz/acre & \\
\hline Sat & $17 \mathrm{Jul}$ & Foliar: 6oz/acre, Drip: 6oz/acre & \\
\hline Sat & $24 \mathrm{Jul}$ & Foliar: 6oz/acre & \\
\hline Sat & $31 \mathrm{Jul}$ & Foliar: 6oz/acre, Drip: 6oz/acre & \\
\hline Sat & 7 Aug & Foliar: 6oz/acre & \\
\hline Sat & 14 Aug & Foliar: 6oz/acre & \\
\hline Mon & 16 Aug & Drip: 6oz/acre. & Pump was broken. \\
\hline Sat & 21 Aug & Foliar: 6oz/acre & \\
\hline Sat & 28 Aug & Foliar: 6oz/acre, Drip: 6oz/acre & \\
\hline Sat & $4 \mathrm{Sep}$ & Foliar: 6oz/acre & \\
\hline Sat & $11 \mathrm{Sep}$ & Foliar: 6oz/acre, Drip: 6oz/acre & \\
\hline Sat & 18 Sep & Foliar: 6oz/acre & \\
\hline Mon & 27 Sep & Drip: 6oz/acre. & Pump was broken. \\
\hline Wed & 29 Sep & Foliar: 6oz/acre. & Too hot. \\
\hline Mon & 4 Oct & Foliar: 6oz/acre. & Rainy weather. \\
\hline Sun & 10 Oct & Foliar: 6oz/acre, Drip: 6oz/acre. & Pump was broken. \\
\hline Sat & 16 Oct & Foliar: 6oz/acre & \\
\hline Sat & 23 Oct & Foliar: 6oz/acre, Drip: 6oz/acre & \\
\hline Sat & 30 Oct & Foliar: 6oz/acre & \\
\hline Sat & $6 \mathrm{Nov}$ & Foliar: 6oz/acre, Drip: 6oz/acre & \\
\hline
\end{tabular}

